\title{
Peripheral tissue-brain interactions in the regulation of food intake
}

\author{
Miguel López ${ }^{1}$, Sulay Tovar ${ }^{1}$, María J. Vázquez ${ }^{1}$, Lynda M. Williams ${ }^{2}$ and Carlos Diéguez ${ }^{1 *}$ \\ ${ }^{1}$ Department of Physiology, School of Medicine, University of Santiago de Compostela, C/ San Francisco s/n 15782, \\ Santiago de Compostela, A Coruña, Spain \\ ${ }^{2}$ Obesity and Metabolic Health Division, Rowett Research Institute, Aberdeen, UK
}

\begin{abstract}
More than 70 years ago the glucostatic, lipostatic and aminostatic hypotheses proposed that the central nervous system sensed circulating levels of different metabolites, changing feeding behaviour in response to the levels of those molecules. In the last 20 years the rapid increase in obesity and associated pathologies in developed countries has involved a substantial increase in the knowledge of the physiological and molecular mechanisms regulating body mass. This effort has resulted in the recent discovery of new peripheral signals, such as leptin and ghrelin, as well as new neuropeptides, such as orexins, involved in body-weight homeostasis. The present review summarises research into energy balance, starting from the original classical hypotheses proposing metabolite sensing, through peripheral tissue-brain interactions and coming full circle to the recently-discovered role of hypothalamic fatty acid synthase in feeding regulation. Understanding these molecular mechanisms will provide new pharmacological targets for the treatment of obesity and appetite disorders.
\end{abstract}

Food intake regulation: Gastrointestinal signals: Adipose and pancreatic hormones: Neural control

The prevalence of overweight and obesity in most developed countries has increased strikingly during the last 30 years (Friedman, 2000, 2003; Flier, 2004; Farooqi \& O'Rahilly, 2005). Body weight depends on the balance between energy intake and energy consumption. Despite wide daily variation in food intake and energy expenditure, for most individuals body weight remains extremely stable over long periods of time. For this stability to occur, feeding and energy expenditure must be constantly modulated and balanced. Obesity results when the former exceeds the latter and there is an accumulation of an excess of fat in peripheral tissues such as white adipose tissue, which is specifically adapted for this function, liver and muscle, which results in metabolic disease (Friedman, 2000, 2003; Flier, 2004; Farooqi \& O'Rahilly, 2005). Obesity has a profound impact on human health and lifespan. Being obese correlates not just with associated metabolic dysfunction such as type 2 diabetes and CVD, but is also associated with the occurrence of certain cancers (Calle \& Kaaks, 2004).
The first hypotheses proposed to explain the peripherybrain interaction in the regulation of food intake were the glucostatic, lipostatic and aminostatic hypotheses. These models proposed that circulating factors, e.g. lipids (lipostatic hypothesis), glucose (glucostatic hypothesis) or protein products (aminostatic hypothesis), that are generated in proportion to body fat stores and/or nutritional status act as signals to the brain, eliciting changes in energy intake and expenditure (Campfield et al. 1996). The current 'obesity epidemic' has driven forward research efforts in the investigation of body-weight homeostasis. For this reason, in the last decade there has been a major increase in the knowledge of the physiological and molecular mechanism regulating body mass. Animals are now known to regulate body weight by a complex homeostatic mechanism involving interactions between peripheral organs and the central nervous system (CNS). Peripheral organs, such as white adipose tissue, gut, thyroid, muscle and gonads produce signals that inform brain centres of the nutritional, as well as metabolic, status of the animal

\footnotetext{
Abbreviations: AgRP, agouti-related peptide; ARC, arcuate nucleus of the hypothalamus; BBB, blood-brain barrier; CART, cocaine- and amphetamineregulated transcript; $\mathrm{CCK}$, cholecystokinin; $\mathrm{CB}$, cannabinoids; CNS, central nervous system; DMH, dorsomedial nucleus of the hypothalamus; EC, endocannabinoids; FAS, fatty acid synthase; GHS-R, growth hormone secretagogue receptor; GLP, glucagon-like peptide; NPY, neuropeptide Y; LHA, lateral hypothalamic area; MCH, melanin-concentrating hormone; MCnR, melanocortin receptor ( $n$ 1-5); NTS, nucleus of the solitary tract; OB-Ra-f, isoforms of leptin receptor; OX, orexin; OXM, oxyntomodulin; POMC, pro-opiomelanocortin; PP, pancreatic polypeptide; PVH, paraventricular nucleus of the hypothalamus; PYY, peptide YY; VMH, ventromedial nucleus of the hypothalamus.

*Corresponding author: Professor Carlos Diéguez, fax +34 981574145, email fscadigo@usc.es
} 
(Flier, 2004; Horvath et al. 2004; Abizaid et al. 2006; Morton et al. 2006). The CNS receives and integrates this entire signalling system, adjusting energy intake (food intake) and energy expenditure, according to the demands of the organism.

The present review summarises the current knowledge about periphery-brain interactions in the regulation of feeding. A full understanding of these mechanisms will allow the establishment of effective therapies to counter eating disorders and obesity.

\section{Gastrointestinal signals regulating food intake}

In addition to its evident function in the digestion and absorption of nutrients, the gut and associated organs (liver, pancreas and visceral white adipose tissue depots) play an important role in the control of energy homeostasis, particularly in the short-term regulation of food intake. Both the enteric nervous system and gut hormones are known to control the initiation and termination of individual meals (Halford \& Blundell, 2000a; Badman \& Flier, 2005; Perez-Tilve et al. 2006).

\section{Enteric nervous system}

The gastrointestinal tract receives a dual extrinsic innervation from the autonomic nervous system via its parasympathetic (cholinergic) division, which includes vagal and pelvic nerves, and its sympathetic (noradrenergic) division, which comprises splanchnic nerves. Parasympathetic innervation is mainly inhibitory, and sympathetic innervation is mainly excitatory. In addition to this autonomic innervation, the gastrointestinal tract also has its own nervous system, i.e. the enteric nervous system (Konturek et al. 2004; Badman \& Flier, 2005), which is involved in every aspect of gut function, from mastication to defaecation. Besides these roles, the enteric nervous system is also implicated in gastric and pancreatic exocrine secretion, gut motility, blood supply and hormone release (Konturek et al. 2004; Badman \& Flier, 2005).

The enteric nervous system projects to the CNS through vagal and sympathetic (spinal) nerves. These projections transmit a variety of information to several CNS areas, including mechanical stimuli (distension, contraction), chemical stimuli (presence of nutrients in the gut lumen) and neurohumoral stimuli (gut hormones, neurotransmitters and neuromodulators; Langley, 1994; Konturek et al. 2004). Most of these afferent vagal fibres terminate in the nucleus of the solitary tract (NTS) in the brainstem, and in laminas $\mathrm{I}$ and $\mathrm{V}$ of the dorsal horn of spinal cord (Maggi, 1991; Konturek et al. 2004). Some signals from the gut are transmitted from the NTS to higher neural centres, such as the paraventricular (PVH) and arcuate (ARC) nuclei of the hypothalamus (Berthoud et al. 1990), the bed nucleus of the stria terminallis and the ventral thalamus. The integration of all these afferent signals related to food presence in the gut regulates the size of individual meals (Flier, 2004; Konturek et al. 2004; Badman \& Flier, 2005).

\section{Gut hormones}

Cholecystokinin. Despite the profuse development of the enteric nervous system, the main route of communication between the brain and the gut in relation to energy homeostasis is via the circulation. One of the hormones first identified in regulating energy homeostasis was the gastrointestinal hormone cholecystokinin (CCK), which is secreted by I cells in the duodenum and the jejunum into the circulation in response to nutrient ingestion (protein and fatty acids; Larsson \& Rehfeld, 1978; Bray, 2000; Halford \& Blundell, 2000a; Badman \& Flier, 2005; Stanley et al. 2005; Perez-Tilve et al. 2006). CCK exists in several molecular forms, the major forms in the plasma being CCK-8, -33 and -39 (Halford \& Blundell, 2000a; Konturek et al. 2004; Stanley et al. 2005). Once secreted, CCK reduces meal size and duration in both man and animals (Gibbs et al. 1973; Kissileff et al. 1981; Smith et al. 1981a; Pi-Sunyer et al. 1982; Muurahainen et al. 1988) and infusion of a CCK antagonist increases energy intake in human subjects (Beglinger et al. 2001). However, despite its anorectic actions, repeated administration of CCK does not influence body weight because although meal frequency is increased, there is no overall change in feeding (West et al. 1984; Wei \& Mojsov, 1995). Thus, CCK is mostly involved in the short-term control of food intake, together with distension of the upper gastrointestinal tract (Konturek et al. 2004; Badman \& Flier, 2005).

CCK signals via two distinct G-protein-coupled receptors termed $\mathrm{CCK}_{\mathrm{A}}$ and $\mathrm{CCK}_{\mathrm{B}}$ (Wank et al. 1992a; Halford $\&$ Blundell, 2000a). Both receptors are widely expressed in the CNS and in the periphery (Moran et al. 1986, 1990; Wank et al. 1992a,b). The effect of CCK on food intake is mediated via $\mathrm{CCK}_{\mathrm{A}}$ (Asin et al. 1992; Halford \& Blundell, 2000a). CCK crosses the brain-blood barrier (BBB; Reidelberger et al. 2004) and acts on neuropeptide $Y$ (NPY) neurons in the dorsomedial nucleus of the hypothalamus (DMH), as well as the NTS in the brainstem (Moran et al. 1997; Bi et al. 2001). The effects of CCK on feeding are also mediated through paracrine and neuroendocrine activation of vagal fibres (Reidelberger \& Solomon, 1986; Schwartz \& Moran, 1994; Moran et al. 1997).

Glucagon-like peptide-1 and oxyntomodulin. The preproglucagon gene product yields two important satiety peptides, glucagon-like peptide (GLP)-1 and oxyntomodulin (OXM; Tang-Christensen et al. 2001; Stanley et al. 2005). The preproglucagon gene is widely expressed in the gut, the pancreas and the NTS in the brainstem. Tissuespecific processing of preproglucagon by prohormone convertases 1 and 2 produces different products: glucagon is the main product in the pancreas; GLP-1 and -2 and OXM are the major products in CNS and gut (TangChristensen et al. 2001; Badman \& Flier, 2005; Stanley et al. 2005).

GLP-1 and OXM are released from L cells in response to NEFA and carbohydrates (Ghatei et al. 1983; Le Quellec et al. 1992; Herrmann et al. 1995; Hirasawa et al. 2005). Both peptides inhibit feeding when they are centrally or peripherally administrated (Turton et al. 1996; 
Dakin et al. 2004), and chronic administration of GLP-1 and OXM decreases weight gain and adiposity in rodents (Meeran et al. 1999; Dakin et al. 2004). The actions of both GLP-1 and OXM on feeding may be mediated via the GLP-1 receptor, which is expressed in the hypothalamus, brainstem and periphery (Uttenthal et al. 1992; Wei \& Mojsov, 1995; Shughrue et al. 1996; Bullock et al. 1996). The anorectic effect of GLP-1 and OXM is also present in man (Flint et al. 1998, 2000, 2001; Gutzwiller et al. 1999; Naslund et al. 1999; Verdich et al. 2001; Meier et al. 2002). Despite this evidence, it has been reported that some of the anorectic effects of GLP-1 may be related to taste aversion and visceral illness (Shughrue et al. 1996; Bullock et al. 1996; Thiele et al. 1997; Yamamoto et al. 2002). Regardless of the anorectic actions of GLP-1 and OXM reported in rodents, GLP-1 receptor-knock-out mice have normal feeding behaviour (Scrocchi et al. 1996, 1997, 2000).

Preproglucagon also yields GLP-2. The role of GLP-2 has not been fully established; however, central administration reduces feeding, probably via GLP-1 receptor (Badman \& Flier, 2005). No effect of GLP-2 on feeding has been reported in man (Schmidt et al. 2003).

Peptide YY. Peptide YY (PYY) is secreted postprandially by the L cells of the gastrointestinal tract, especially in the most distal portions such as the ileum, colon and rectum; PYY secretion is correlated with energy intake (Stanley et al. 2005). There are two main forms of PYY in the circulation: $\mathrm{PYY}_{1-36}$ and $\mathrm{PYY}_{3-36}$ (Grandt et al. 1994; Batterham et al. 2002; Wynne et al. 2004; Stanley et al. 2005). Peripheral administration of PYY has several actions, including delaying gastric emptying and gastric secretion, and increasing ileum absorption. It has also been reported that peripheral administration of $\mathrm{PYY}_{3-36}$ inhibits food intake and reduces weight gain in rodents, primates and man (Batterham et al. 2002; Challis et al. 2003; Moran et al. 2005). PYY crosses the BBB and probably exerts its actions via the presynaptic $\mathrm{Y}_{2}$ receptor of NPY neurons in the ARC, releasing inhibition of pro-opiomelanocortin (POMC) neurons and consequently inhibiting feeding (Broberger et al. 1997; Batterham et al. 2002; Challis et al. 2003).

Despite this evidence, the anorectic effect of $\mathrm{PYY}_{3-36}$ is controversial and not easily duplicated (Tschop et al. 2004; Coll et al. 2004a). Indeed, in contrast to peripheral injection, central administration of both $\mathrm{PYY}_{1-36}$ and $\mathrm{PYY}_{3-36}$ stimulates feeding in rodents (Stanley et al. 1985; Clark et al. 1987; Hagan et al. 1998; Corpa et al. 2001). It has also been suggested that the anorexic effect of PYY may be partially mediated by an aversive response (Halatchev \& Cone, 2005).

Bombesin. Bombesin is a peptide that is widely distributed in the mammalian gut. Plasma levels of bombesin increase markedly after food intake (Gibbs et al. 1979; Wynne et al. 2004), and peripheral and central administration of bombesin is anorectic (Gibbs et al. 1979; Smith et al. 1981b). Bombesin is structurally very similar to gastrin-releasing peptide and neuromedin $\mathrm{B}$, and binds to their receptors. Additionally, a bombesin-3 receptor has been cloned (Ladenheim et al. 1997). Knocking out bombesin-3 receptor induces moderate hyperphagia, obesity and metabolic alterations in mice (Ohki-Hamazaki et al. 1997).

Gastric inhibitory polypeptide. Gastric inhibitory polypeptide is secreted from the duodenal $\mathrm{K}$ cells, predominantly in response to ingested fat. Mice fed a high-fat diet have increased levels of gastric inhibitory polypeptide together with obesity (Wynne et al. 2004; Badman \& Flier, 2005), whereas mice lacking the gastric inhibitory polypeptide receptor are protected against obesity induced by both a high-fat diet and leptin deficiency (ob/ob mice; Miyawaki et al. 2002). Thus, gastric inhibitory polypeptide may be involved in the development of obesity in response to high fat intake.

Ghrelin. Ghrelin is a twenty-eight-amino acid acylated hormone mainly synthesised and secreted by the gut in the gastric oxyntic cells (A/X cells) at the fundus of the stomach, as well as the duodenum, ileum, caecum and colon (Kojima et al. 1999; Date et al. 2000; Gualillo et al. 2001; Sakata et al. 2002). Ghrelin expression has also been detected in other tissues, such as the hypothalamus (Kojima et al. 1999; Horvath et al. 2001; Cowley et al. 2003) testis (Barreiro et al. 2002; Tena-Sempere et al. 2002), pituitary (Caminos et al. 2003a), ovary (Caminos et al. 2003b; Gaytan et al. 2003), heart (Iglesias et al. 2004) and placenta (Gualillo et al. 2001).

Ghrelin, which was initially identified as the endogenous ligand of the growth hormone secretagogue receptor (GHS-R), exerts a potent and specific growth hormonereleasing activity in vitro (Kojima et al. 1999) and in vivo (Arvat et al. 2000; Seoane et al. 2000), as well as increasing the transcription rate of the Pit- 1 gene (García et al. 2001). Further studies have led to the recognition that ghrelin also plays an important role in energy homeostasis. Ghrelin administration induces positive energy balance in rodents by decreasing fat utilisation without markedly changing energy expenditure or locomotor activity (Wren et al. 2000; Nakazato et al. 2001). Furthermore, peripheral and central administration of ghrelin to rodents increases feeding, as well as fat mass, and reduces fat utilisation (Tschop et al. 2000; Nakazato et al. 2001; Wren et al. 2001b; Seoane et al. 2003). Plasma levels of ghrelin are regulated by food intake, rising during fasting and immediately before meals, and falling after food intake (Ariyasu et al. 2001; Cummings et al. 2001; Tschop et al. 2001a). These changes in ghrelin expression are directly modulated by energy intake and nutritional signals such as blood glucose and ingestion of fat or carbohydrate (Tschop et al. 2000; Sakata et al. 2002). For this reason a physiological role of ghrelin in meal initiation has been proposed (Cummings et al. 2001; Cummings \& Shannon, 2003). This suggestion is supported by experiments (Nakazato et al. 2001) that use anti-ghrelin antibodies to block the actions of ghrelin, which results in an attenuation of fasting-induced refeeding.

The effects of ghrelin on feeding and growth hormone secretion are mediated via type 1a GHS-R (Kojima et al. 1999; Tschop et al. 2000; Chen et al. 2004; Sun et al. 2004). However, the orexigenic effects of ghrelin are independent of growth hormone-releasing properties (Tschop et al. 2000; Shintani et al. 2001; Tamura et al. 2002). The expression of GHS-R in the hypothalamus is 
(a)

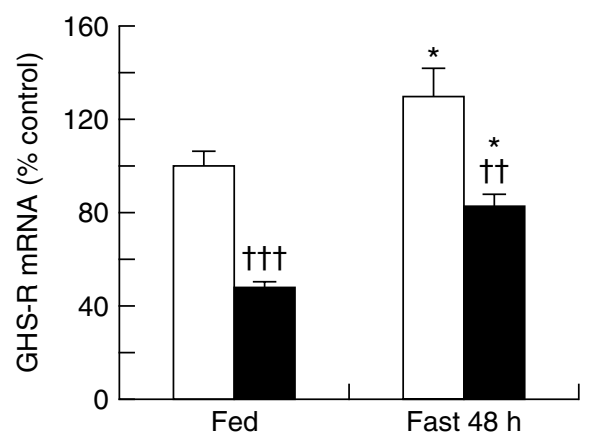

(c)

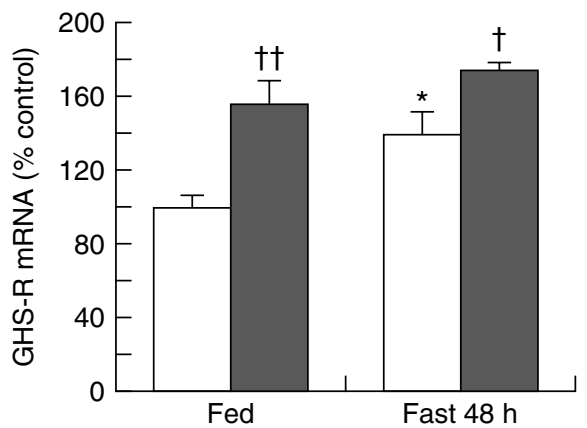

(b)

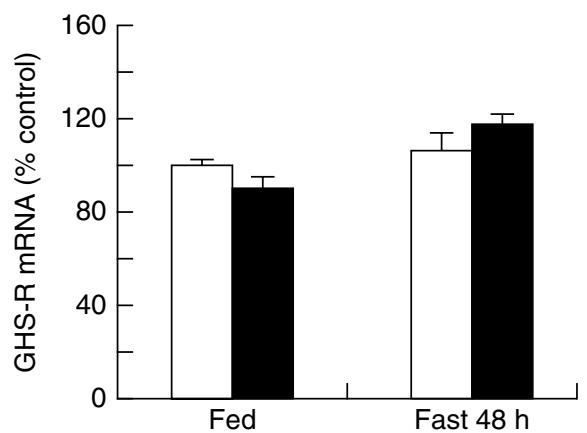

(d)

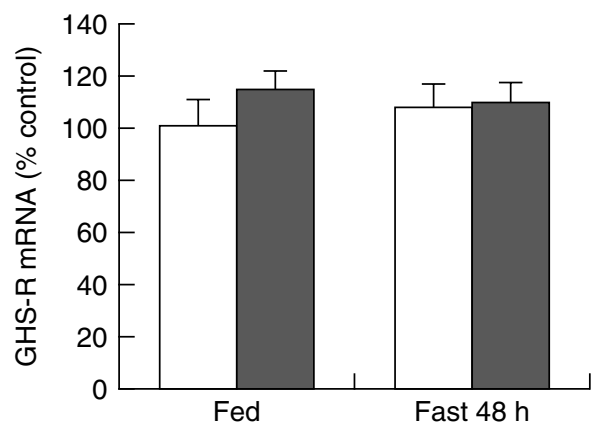

Fig. 1. Regulation of growth hormone secretogogue receptor (GHS-R) in the rat hypothalamus by leptin and ghrelin. Effects of intracerebroventricular leptin ( $\square$; a, b) and ghrelin $(\square ; c, d)$ on GHS-R expression in the arcuate nucleus $(a, c)$ and the ventromedial nucleus of the hypothalamus (b, d) in fed and 48 h-fasted rats. ( $\square$ ), Vehicle. Values are means with their standard errors represented by vertical bars. Mean values were significantly different from the corresponding values for fed rats: ${ }^{*} P<0 \cdot 05$. Mean values were significantly different from the corresponding values for vehicle-fed or vehicle-48 h-fasted rats: $\uparrow P<0.05, \dagger P<0.01, \dagger_{\dagger}+P<0.001$.

nutritionally regulated in a nucleus-specific manner, with fasting increasing the mRNA levels of GHS-R in the ARC but not in the ventromedial nucleus of the hypothalamus (VMH). Additionally, the level of GHS-R expression in the ARC, but not in the VMH, is reduced by leptin and increased by ghrelin in a growth hormone-dependent fashion (Fig. 1; Nogueiras et al. 2004b).

Ghrelin is also important in the regulation of energy homeostasis in man. Intravenous administration of ghrelin to healthy volunteers increases food intake (Wren et al. 2001a). Moreover, the rise in preprandial ghrelin correlates with hunger scores in human subjects eating spontaneously (Cummings et al. 2004). Interestingly, the levels of ghrelin are correlated with adiposity in man, with an inverse relationship between plasma ghrelin levels and BMI (Tschop et al. 2001b). Obese human subjects show reduced levels of plasma ghrelin, which rise to normal after diet-induced weight loss (Hansen et al. 2002; Cummings et al. 2002b). Moreover, in obese individuals the postprandial regulation of ghrelin seems to be altered, which may be related to continuous food intake and/or obesity (English et al. 2002). Finally, the severe hyperphagia seen in patients with Prader-Willi syndrome is associated with elevated ghrelin levels, in contrast to other forms of obesity in which ghrelin levels are low (Cummings et al. 2002a).

In the CNS the action of ghrelin on feeding is mainly exerted via the ARC. GHS-R mRNA is expressed in neurons in the ARC co-expressing NPY and agouti-related peptide (AgRP; Guan et al. 1997; Tannenbaum et al. 1998; Willesen et al. 1999; Zigman et al. 2006), and the central administration of ghrelin increases the mRNA content of NPY and AgRP in the ARC in fed and fasting conditions (Kamegai et al. 2001; Nakazato et al. 2001; Seoane et al. 2003). There is also some evidence that orexin (also termed hypocretin; OX) neurons in the lateral hypothalamic area (LHA; Lawrence et al. 2002; Toshinai et al. 2003) and neurons in the NTS and the area postrema in the brainstem may mediate the orexigenic actions of ghrelin (Nakazato et al. 2001; Lawrence et al. 2002). Recent data also indicate that ghrelin acts in the hypothalamus by altering fatty acid metabolism and AMP-activated protein kinase. It has been demonstrated that ghrelin increases hypothalamic AMP-activated protein kinase phosphorylation levels, activating it. This action may be associated to specific changes in hypothalamic neuropeptides, although the exact molecular mechanisms and anatomical details of this interaction have not been fully identified (Andersson et al. 2004; Kola et al. 2005).

Despite ghrelin having a potent action in regulating food intake, both ghrelin-knock-out mice and mice lacking GHS-R type 1a have normal feeding patterns and body composition on a standard diet (Sun et al. 2003). However, on a high-fat diet the absence of ghrelin (Wortley et al. 2005) or the ghrelin receptor (Zigman et al. 2005) protects 
against early-onset obesity; in both cases this reduced weight gain is associated with decreased adiposity and increased energy expenditure and locomotor activity. These data suggest that ghrelin, like leptin, may play an important role in the development of hypothalamic systems regulating energy balance (Grove \& Cowley, 2005). Very interestingly, elimination of ghrelin improves the diabetic phenotype but not the obese phenotype of $o b / o b$ mice (Sun et al. 2006).

Finally, it has recently been reported that obestatin, a new peptide derived from the ghrelin gene, inhibits food intake by acting through the orphan receptor GPR39 (Nogueiras \& Tschop, 2005; Zhang et al. 2005). Despite this evidence there are some discrepancies in relation to the anorectic effect of obestatin (Nogueiras et al. 2006) as well as its binding to GPR39 (Holst et al. 2006). If the anorectic effect is confirmed, this finding could provide a new drug target for the treatment of obesity.

\section{Adipose tissue hormones}

Originally thought of as an inert tissue involved in the storage of energy, it is now clear that adipose tissue is an active endocrine organ (Casanueva \& Diéguez, 1999; Ahima \& Flier, 2000a). Adipocyte hormones regulate appetite, glucose homeostasis, lipid metabolism, endocrine function, cardiovascular physiology, reproduction, immune function and development, amongst other functions (Casanueva \& Diéguez, 1999; Ahima \& Flier, 2000a; Pinto et al. 2004; Horvath \& Diano, 2004).

\section{Leptin}

Among the adipocyte hormones, the one that has most changed the concept of white adipose tissue as an inert tissue is leptin, the product of the $o b$ (obese) gene (Zhang et al. 1994). Leptin is expressed principally in adipocytes (Zhang et al. 1994), but also at lower levels in the gastrointestinal tract (Bado et al. 1998) and placenta (Señarís et al. 1997; Masuzaki et al. 1997). Plasma leptin levels reflect both energy stores and acute energy balance. Circulating leptin levels are tightly correlated with adipose tissue mass (Maffei et al. 1995), and food restriction results in suppression of circulating leptin (Frederich et al. 1995; Maffei et al. 1995), which can be reversed by refeeding or insulin administration. Peripheral and central leptin administration reduces spontaneous and fastinginduced hyperphagia (Ahima et al. 1996; Ahima, 2000), and chronic peripheral administration reduces feeding, resulting in loss of fat mass and body weight (Halaas et al. 1995).

The complete lack of leptin seen in the $o b / o b$ mouse has profound consequences on body-weight homeostasis, leading to hyperphagia and obesity, as well as neuroendocrine and immune dysregulation, which is normalised by leptin administration (Campfield et al. 1995; Halaas et al. 1995; Pelleymounter et al. 1995). In man leptin deficiency causes morbid obesity and hypogonadism (Montague et al. 1997; Strobel et al. 1998), which can be improved by recombinant leptin (Farooqi et al. 1999; Licinio et al.
2004). In the same way, defective leptin receptor signalling also has a profound impact on body weight and endocrine function. A point mutation in the intracellular domain of the long isoform of the leptin receptor (OB-Rb) gene, which prevents signalling, results in obesity in $d b / d b$ mice (Chen et al. 1996; Lee et al. 1996). Defects in the human leptin receptor have also been reported; as with leptin deficiency, these subjects have hypogonadism and earlyonset morbid obesity (Clement et al. 1998, 2002).

Leptin binds and activates a receptor of the cytokine receptor family (Tartaglia et al. 1995). Alternative mRNA splicing and post-translational processing results in several isoforms of the receptor (OB-Ra, OB-Rb, OB-Rc, OB-Re and OB-Rf; Tartaglia, 1997; Chua et al. 1997; Ahima \& Flier, 2000b). OB-Rb is the variant implicated in signal transduction (Tartaglia, 1997; Ahima \& Flier, 2000b). The other isoforms may act as leptin sequesters and transporters, binding leptin without signal transduction (Friedman \& Halaas, 1998; Ahima \& Flier, 2000b). Ob-Rb possesses a long intracellular domain that binds to janus kinases (Lee et al. 1996) and to signal transducer and activator of transcription-3 transcription factors (Vaisse et al. 1996; Hakansson et al. 1999), resulting in signal transduction and mediating the action of leptin on feeding (Lee et al. 1996). Activation of the janus kinases/signal transducers and activators of transcription pathway induces expression of suppressor of cytokine signalling-3, a cytokine-inducible inhibitor of signalling; suppressor of cytokine signalling-3 expression is up regulated by leptin in hypothalamic nuclei expressing the Ob-Rb receptor (Ahima \& Flier, 2000b; Howard et al. 2004).

Plasma leptin crosses the BBB via a saturable process (Banks et al. 1996; Banks 2001a,b), thought to be mediated by OB-Ra and OB-Rc (El Haschimi et al. 2000; Ahima \& Flier, 2000b). OB-Rb is widely expressed in the hypothalamus (being most abundant in the ARC, the VMH and the DMH) the LHA and the medial preoptic area (Fei et al. 1997; Elmquist et al. 1998; Hakansson et al. 1998, 1999). OB-Rb is also expressed in feeding-modulating neurons in the brainstem (Elmquist et al. 1997; Mercer et al. 1998). In the ARC OB-Rb mRNA is expressed by the two major neuronal groups: neurons co-expressing the orexigenic neuropeptides NPY and AgRP (Mercer et al. 1996; Cheung et al. 1997); a distinct second population of neurons co-expressing the anorexigenic POMC and cocaine- and amphetamine-regulated transcript (CART). Leptin inhibits the activity of orexigenic AgRP/NPY neurons and reduces expression of AgRP and NPY (Stephens et al. 1995; Hahn et al. 1998; Elias et al. 1999), while activating anorectic CART/POMC neurons (Schwartz et al. 1997; Kristensen et al. 1998; Swart et al. 2002). In the LHA leptin receptor is expressed in neurons expressing the orexigenic neuropeptides melanin-concentrating hormone $(\mathrm{MCH})$ and the $\mathrm{OX}$, which are inhibited by leptin $(\mathrm{Qu}$ et al. 1996; López et al. 2000). When leptin levels are low, such as in food restriction and fasting, the expression of orexigenic neuropeptides is increased and orexigenic neurons are activated; in contrast, anorexigenic neuropeptides are decreased and anorexigenic neurons are inhibited. When plasma leptin levels are high, as in the satiated animal, the anorectic pathways are switched on and the 
orexigenic pathways are switched off (Friedman \& Halaas, 1998; Kalra et al. 1999; Saper et al. 2002; Flier, 2004).

The role of leptin in human obesity is intriguing. As described earlier, while there are individuals with defects in leptin synthesis or leptin signalling, these cases are extremely rare. The majority of obese individuals are characterised by high levels of leptin (Maffei et al. 1995; Considine et al. 1996), suggesting leptin insensitivity or resistance; in fact, leptin administration to obese subjects has only a moderate effect on body weight (Heymsfield et al. 1999; Fogteloo et al. 2003). In rodents diet-induced obesity has also been correlated with the development of leptin resistance (Van Heek et al. 1997; Levin \& DunnMeynell, 2002). Leptin resistance may develop via different mechanisms. Peripheral leptin resistance may be the result of impairment in the function of the saturable leptin transporters in the BBB (Burguera et al. 2000; Furuhata et al. 2000; Levin et al. 2004). Central leptin resistance may develop as a result of impaired leptin signalling via $\mathrm{OB}-\mathrm{Rb}$ in the hypothalamus, which could be related to a decrease in OB-Rb expression (García et al. 2000; Seeber et al. 2002; López et al. 2005a), a defect in the intracellular signalling mechanism of the janus kinases/signal transducers and activators of transcription pathway or the over-expression of suppressor of cytokine signalling-3 (El Haschimi et al. 2000; Howard et al. 2004; Ladyman \& Grattan, 2004; Levin et al. 2004; Munzberg et al. 2004; Munzberg \& Myers, 2005).

The role of leptin in the hypothalamus is not only associated with food-intake regulation. Leptin also contributes to the adaptation of the neuroendocrine axis to fasting (Ahima et al. 1996; Casanueva \& Diéguez, 1999). Additionally, leptin is a neurotrophic factor during the development of the hypothalamus, mediating neuronal plasticity (Bouret et al. 2004a,b; Bouret \& Simerly, 2004; Pinto et al. 2004). The importance of this function of leptin in the context of obesity is still not clear, but it has been proposed that perturbations in perinatal nutrition that alter leptin levels may have long-term consequences for the formation and function of hypothalamic circuits regulating feeding and body weight in adulthood (López et al. $2005 a$ ).

\section{Adiponectin}

Adiponectin, also termed adipocyte complement-related protein, apM1 or adipoQ, is a 244-amino acid protein secreted from adipose tissue (Hu et al. 1996; Berg et al. 2002; Tsao et al. 2002), the placenta (Caminos et al. 2005) and cardiomyocytes (Pineiro et al. 2005). Adiponectin has four domains: an amino-terminal signal sequence; a region without homology to other known proteins; a collagen-like region; a carboxy-terminal globular domain. The globular domain forms homotrimers, and additional interactions with collagenous segments cause the formation of highermolecular-weight complexes (Pajvani et al. 2003).

Adiponectin is important in the regulation of energy homeostasis (Scherer et al. 1995). Plasma levels of adiponectin are inversely correlated with adiposity in several species, including man (Hu et al. 1996; Arita et al. 1999; Hotta et al. 2001) Adiponectin is increased after food restriction in rodents (Berg et al. 2001, 2002). Peripheral administration to rodents has been shown to attenuate body-weight gain, by increased $\mathrm{O}_{2}$ consumption, without affecting food intake (Berg et al. 2001; Fruebis et al. 2001; Yamauchi et al. 2003). This effect on energy expenditure appears to be mediated by the hypothalamic melanocortin system, without affecting other neuropeptide systems regulated by leptin (Qi et al. 2004). Circulating adiponectin levels negatively correlate with insulin resistance (Hotta et al. 2001), and treatment with adiponectin can reduce body-weight gain, increase insulin sensitivity and decrease lipid levels in rodents (Berg et al. 2001; Yamauchi et al. 2001; Qi et al. 2004; Winzell et al. 2004). Adiponectin-knock-out mice have severe diet-induced insulin resistance (Maeda et al. 2002). The mechanism by which adiponectin improves insulin resistance and glucose metabolism is not fully understood, but some of these effects may be mediated by activation of AMP-activated protein kinase (Yamauchi et al. 2002).

Adiponectin binds and activates two known membrane receptors, adipoR1 and adipoR2 (Yamauchi et al. 2003). AdipoR1 is highly expressed in skeletal muscle; it has a high affinity for the globular domain of adiponectin and low affinity for the full-length ligand. AdipoR2 is highly expressed in the liver and preferentially binds to the full-length ligand. Adiponectin receptors have also been detected in the hypothalamus (Qi et al. 2004) and the placenta (Caminos et al. 2005). Very interestingly, it has recently been reported that adiponectin does not cross the BBB but modifies cytokine expression in the brain endothelial cells, making unlikely a direct effect of adiponectin in the CNS (Spranger et al. 2006).

\section{Resistin}

Resistin is produced by adipose tissue and appears to be involved in the modulation of insulin sensitivity and adipocyte differentiation (Steppan et al. 2001a,b; VidalPuig \& O'Rahilly, 2001; Steppan \& Lazar, 2002). In addition to adipose tissue, resistin is also expressed in the stomach, intestine, adrenal gland, testis and skeletal muscle (Nogueiras et al. 2003a,b, 2004a).

Resistin expression is regulated in a tissue- and genderspecific manner. Food deprivation leads to a decrease in resistin mRNA expression only in adipose tissue (Nogueiras et al. 2003a,b). Circulating resistin is increased in obese rodents (Steppan et al. 2001a) and man (Savage et al. 2001) and falls after weight loss in man (Valsamakis et al. 2004). Resistin-knock-out mice display increased glucose tolerance on a high-fat diet (Banerjee et al. 2004; Sul, 2004) and transgenic mice over-expressing a dominant negative form of resistin show increased adiposity with elevated plasma leptin and adiponectin levels, as well as enhanced glucose tolerance and insulin sensitivity (Sul, 2004). All this evidence suggests that resistin may contribute to the development of insulin resistance and diabetes in obesity (Steppan et al. 2001a,b; Vidal-Puig \& O'Rahilly, 2001; Steppan \& Lazar, 2002). In support of this role, recent evidence has shown that resistin inhibits feeding through a hypothalamic mechanism (Tovar et al. 
2005). However, the molecular details of that action are not fully established.

\section{IL-6 and IL-1}

IL-6 is a multifunctional immune-modulating cytokine that has been suggested to have important functions in glucose and lipid metabolism. IL-6 is secreted from adipose tissue into the circulation, and its expression is positively correlated with BMI and total fat tissue. IL-6-knock-out mice develop obesity, which can partly be reversed by IL-6 replacement, suggesting a role for IL-6 in the long-term regulation of adipose tissue mass (Wallenius et al. 2002b). Furthermore, central administration of a low dose of IL-6 decreases feeding and increases energy expenditure in rats, suggesting a central site of action for IL-6 (Wallenius et al . 2002a). Supporting this hypothesis it has also been suggested that IL-6 and IL-6 receptors are expressed in the neurons in the VMH and the DMH (Schobitz et al. 1993). IL-1 is also involved in body-weight homeostasis. IL-1 type I receptor-knock-out mice display an obese and insulin-resistant phenotype. This obese phenotype is characterised by a decrease in leptin sensitivity, fat utilisation and locomotor activity (García et al. 2006).

\section{Pancreatic hormones}

\section{Insulin}

Insulin is also an adiposity signal. Plasma insulin concentrations correlate with peripheral insulin sensitivity, which in turn is linked to total body fat depots and fat distribution, visceral fat being a key determinant (Schwartz et al. 1992a, 2000).

Insulin secretion by the pancreas increases rapidly after a meal, exerting an anorectic effect via the CNS (Schwartz et al. 1992a, 2000). Insulin enters the CNS via saturable receptor-mediated transport across the BBB (Woods et al. 2003). Central administration of insulin or insulin mimetic reduces feeding and body weight in rodents and primates (Woods et al. 1979; Schwartz et al. 1992a, 2000; Air et al. 2002). Administration of antisense RNA against the insulin receptor induces hyperphagia and increased fat mass (Obici et al. 2002a), and neuron-specific deletion of the insulin receptor results in obesity, hyperinsulinaemia and dyslipidaemia in mice (Bruning et al. 2000). Insulin receptors are widespread in the brain and occur in hypothalamic nuclei involved in food intake (ARC, DMH, PVH and periventricular nucleus; Corp et al. 1986; Marks et al. 1990). In the hypothalamus the actions of insulin on food intake and body weight are mediated by NPY (Schwartz et al. 1992b) and the melanocortin system (Sipols et al. 1995; Obici et al. 2001; Benoit et al. 2002).

\section{Pancreatic polypeptide}

Pancreatic polypeptide (PP) belongs to the PP-fold family of peptides, which also includes PYY and NPY (Conlon, 2002). PP is mainly produced by peripheral cells of the islets of Langerhans, the exocrine pancreas and the distal gastrointestinal tract (Small \& Bloom, 2004; Stanley et al.
2005). Plasma PP concentrations increase proportionally to energy intake (Small \& Bloom, 2004; Stanley et al. 2005), and they appear to be inversely proportional to adiposity, with high levels in anorexic subjects and reduced levels in obese subjects (Lassmann et al. 1980; Fujimoto et al. 1997).

Peripheral PP administration reduces feeding and body weight in obese rodents (Malaisse-Lagae et al. 1977) and feeding in man (Batterham et al. 2003). The anorectic effect of PP is exerted via brainstem pathways (in the area postrema), regulation of hypothalamic neuropeptides (NPY and $\mathrm{OX}$ ) and modulation of ghrelin expression (Asakawa et al. 2003). The anorectic effect of PP is mediated by $\mathrm{Y}_{5}$ receptor. In contrast to the peripheral actions, central administration of PP increases food intake (Clark et al. 1984); the receptors mediating this action and the mechanisms involved are unclear.

\section{Neural control of food intake}

\section{Hypothalamic regulation of food intake}

The CNS receives information from the sensory experience of eating and also from the process of ingestion, absorption, metabolism and energy storage. The original theories explaining the central control of food intake were based on a 'dual-centre hypothesis' (Hecherington \& Ranson, 1942; Anand \& Brobeck, 1951). In this model, based on hypothalamic-lesioning experiments, feeding is controlled by two hypothalamic areas: the lateral hypothalamic 'feeding centres' and the ventromedial hypothalamic 'satiety centres'. Lesions of the LHA decrease food intake and eventually lead to starvation and death. Conversely, lesions of several of the mediobasal hypothalamic nuclei result in obesity. Since then, knowledge concerning the hypothalamic regulation of feeding has increased; however, the main concept is the same, i.e. that anatomically-defined hypothalamic areas regulate food intake. These hypothalamic nuclei form interconnected neuronal circuits that respond to changes in energy status by altering the expression of specific neuropeptides, resulting in changes in energy intake and expenditure (Friedman \& Halaas, 1998; Kalra et al. 1999; Schwartz et al. 2000; Saper et al. 2002; Flier, 2004; Abizaid et al. 2006; Morton et al. 2006). Table 1 summarises some hypothalamic neuropeptides and neurotransmitters regulating food intake.

\section{Hypothalamic neuronal pathways regulating appetite}

Arcuate nucleus. The ARC is considered as the 'master hypothalamic centre' for feeding control. It is situated around the base of the third ventricle and lies immediately above the median eminence. The ARCmedian eminence is a circumventricular organ in which the BBB is modified, allowing the entry of peptides and proteins from the circulation, such as PYY, GLP-1, leptin and insulin (Banks et al. 1996; Kastin et al. 2002; Nonaka et al. 2003; Woods et al. 2003).

Two distinct neuronal populations in the ARC integrate peripheral nutritional and/or feeding signals. One set of neurons in the ventromedial part of the ARC express the 
Table 1. Molecules with demonstrated orexigenic and/or anorexigenic effects in some animal models

\begin{tabular}{|c|c|c|c|}
\hline \multicolumn{2}{|c|}{ Orexigenic: feeding stimulators } & \multicolumn{2}{|c|}{ Anorexigenic: feeding inhibitors } \\
\hline 26RF amide & Somatostatin* & Adiponectin & Neuromedin B \\
\hline \multirow[t]{2}{*}{ Agouti-related peptide } & \multirow{2}{*}{$\begin{array}{l}\text { Thyroid hormones } \\
\text { (tri-iodothyronine) }\end{array}$} & Amylin & Neuromedin S \\
\hline & & Anorectin & Neuromedin U \\
\hline$\gamma$-Aminobutyric acid & VGF (non-acronymic) & Bombesin & Neuropeptide B \\
\hline Beacon & & Brain-derived neurotrophic factor & Neuropeptide K \\
\hline$\beta$-Endorphin & & Calcitonin-gene related peptide & Neuropeptide S \\
\hline Corticosterone & & Cocaine- and amphetamine-regulated & Neuropeptide W \\
\hline Dopamine & & transcript & \\
\hline Dynorphin & & Cholecystokinin & Neurotensin \\
\hline Endocannabinoids & & Ciliary neurotrophic factor & Obestatin? \\
\hline Galanin & & Corticotrophin-releasing hormone & Oleoylethanolamide \\
\hline Galanin-like peptide & & Enterostatin & Oleoyl-estrone \\
\hline Growth hormone & & Galanin-like peptide & Oxyntomodulin \\
\hline Growth hormone-releasing & & Glucagon-like peptide-1 & Oxytocin \\
\hline hormone & & Insulin & Pancreatic polypeptide \\
\hline Glutamate & & Insulin-like growth factors-I and-II & Prolactin-releasing peptide \\
\hline Ghrelin & & $\mathrm{IL}-1$ & Peptide $Y_{3} Y_{36}$ \\
\hline Melanin-concentrating & & IL-6 & Resistin \\
\hline hormone & & Long chain fatty acids & Serotonin \\
\hline Motilin & & Leptin & Somatostatin* \\
\hline Noradrenaline & & $\alpha$-Melanocyte-stimulating hormone & Thyrotrophin-releasing \\
\hline Neuropeptide $Y$ & & & hormone \\
\hline Oestrogens & & Nesfatin-1 & Urocortin \\
\hline Orexins $(A$ and $B)$ & & & \\
\hline
\end{tabular}

*The effect of somatostatin on food intake has been reported to be contradictory and very dependent of the doses used. Low doses increase feeding and high doses decrease feeding (Feifel \& Vaccarino, 1989, 1990, 1994).

orexigenic neuropeptides NPY and AgRP (Broberger et al. 1998b; Hahn et al. 1998). These neurons mostly project to the PVH. In the ventrolateral part of the ARC there is a second population of neurons that express the anorexigenic products of POMC, the precursor of $\alpha$-melanocytestimulating hormone, and also CART (Elias et al. 1998a; Kristensen et al. 1998). This set of neurons projects more broadly within the CNS to hypothalamic nuclei such as the $\mathrm{DMH}$, the LHA and the perifornical area, as well as the PVH. Thus, AgRP/NPY and CART/POMC neurons act as the primary hypothalamic site of action of peripheral hormones such as insulin and leptin. ARC neurons, in turn, project to secondary hypothalamic nuclei ('second order neurons') such as the PVH and the LHA. In these secondorder neurons the release of neuropeptides is regulated to modulate energy intake (Schwartz et al. 2000; Flier, 2004).

Paraventricular nucleus. The PVH integrates neuropeptide signals from numerous CNS regions, including the ARC and brainstem (Sawchenko \& Swanson, 1983). Administration into the PVH of almost all of the known orexigenic and anorexigenic signalling molecules alters appetite (Kalra et al. 1999). Furthermore, CART/POMC neurons originating in the ARC potentiate inhibitory $\gamma$-aminobutyric acidergic signalling in the PVH and reduce feeding, while AgRP/NPY neurons inhibit this $\gamma$-aminobutyric acidergic signalling and stimulate food intake (Cowley et al. 1999). Despite the large number of neuropeptides acting on the PVH, recent work suggests that they act to regulate feeding through a common mechanism involving AMP-activated protein kinase (Minokoshi et al. 2004).
The PVH also plays a major role in the integration of food intake and neuroendocrine function. AgRP/NPY and CART/POMC neurons in the ARC project to thyrotrophinreleasing hormone neurons in the PVH (Legradi \& Lechan, 1999; Fekete et al. 2000). AgRP/NPY inhibits pro-thyrotrophin-releasing hormone gene expression (Fekete et al. 2002), while $\alpha$-melanocyte-stimulating hormone stimulates pro-thyrotrophin-releasing hormone expression and inhibits the fasting-induced suppression of thyrotrophin-releasing hormone (Fekete et al. 2000). The PVH also contains corticotrophin-releasing hormone neurons, which form reciprocal circuits with NPY neurons in the ARC (Kalra et al. 1999).

Ventromedial nucleus of the hypothalamus. The VMH (as distinct from thalamic ventromedial nucleus) has long been considered as the 'satiety centre', since the finding that bilateral lesions in this nucleus induce hyperphagia and obesity (Hecherington \& Ranson, 1942; Anand \& Brobeck, 1951). The VMH mainly receives projections from AgRP/NPY and CART/POMC neurons in the ARC. Additionally, the $\mathrm{VMH}$ neurons project their axons to the ARC, DMH and LHA, as well as brainstem regions such as the NTS (Kalra et al. 1999; Pinto et al. 2004; Sternson et al. 2005).

The VMH has been considered as a 'reception nucleus' for peripheral signals, as well as central signals. VMH neurons show a high abundance of leptin, ghrelin, oestrogen, thyroid hormone and neuropeptide receptors (Shughrue et al. 1997; Roselli et al. 1997; Kalra et al. 1999; Nogueiras et al. 2004b; King, 2006). However, despite the identification of these receptors, the molecular mechanisms regulating feeding in the $\mathrm{VMH}$ have not yet been well 
established. Some evidence suggests that brain-derived neurotrophic factor and steroidogenic factor-1 may play crucial roles in mediating body weight in this nucleus. Mice with reduced brain-derived neurotrophic factor receptor expression (Xu et al. 2003), and with reduced brainderived neurotrophic factor signalling (Xu et al. 2003), and also steroidogenic factor-1-knock-out mice (Majdic et al. 2002), have increased body weight. Furthermore, activation of steroidogenic factor-1 neurons by leptin is required for normal body-weight homeostasis (Dhillon et al. 2006). Finally, it has recently been reported that fatty acid synthase (FAS) and malonyl-CoA levels in this nucleus may play an important physiological role in the regulation of feeding (López et al. 2006).

Dorsomedial nucleus of the hypothalamus. Like the $\mathrm{VMH}$, the DMH has long been considered to be an integrative centre, processing information from other hypothalamic areas (Kalra et al. 1999). The DMH is located immediately dorsal to the VMH and has extensive direct connections with other hypothalamic nuclei (e.g. the PVH and the LHA), as well as the brainstem (Kalra et al. 1999; Bellinger \& Bernardis, 2002). Destruction of the DMH induces hyperphagia and obesity, although less dramatically than VMH lesions (Bellinger \& Bernardis, 2002). Very recent evidence has also demonstrated that the DMH is critical for the expression of food-entrainable circadian rhythms (Gooley et al. 2006).

The DMH contains NPY-expressing cell bodies, which are involved in the hyperphagia observed in pregnant and lactating rats ( $\mathrm{Li}$ et al. 1998; García et al. 2003). Moreover, CART-expressing neurons are highly abundant in the $\mathrm{DMH}$; the exact function of these cells is unknown, but they are probably involved in fasting-induced responses (Henry et al. 2001).

Lateral hypothalamic area. Although the involvement of the LHA, including the perifornical area, in the regulation of feeding has been known for $>60$ years (Hecherington \& Ranson, 1942; Anand \& Brobeck, 1951), the molecular mechanisms involved had remained unknown until 15 years ago when $\mathrm{MCH}$ was identified as the first orexigenic peptide exclusively expressed in this nucleus (Qu et al. 1996). Other neuropeptides important in the regulation of feeding are also highly expressed in this area, such as galanin (Hakansson et al. 1998), dynorphin (Chou et al. 2001), CART-encoded peptides (Koylu et al. 1998) and OX (de Lecea et al. 1998; Sakurai et al. 1998; López et al. 2005b).

$\mathrm{MCH}$ and prepro-OX are each expressed by a different cell population, both of which receive projections from AgRP/NPY and CART/POMC neurons in the ARC (Broberger et al. 1998a; Elias et al. 1998b; Horvath et al. 1999). Additionally, both sets of neurons express leptin receptors, indicating that their actions may be integrated (Hakansson et al. 1998, 1999). The LHA also contains a large number of glucose-sensing neurons (Bernardis \& Bellinger, 1996). OX neurons in the LHA respond to a fall in glucose levels with an increase in activity (Cai et al. 1999; Moriguchi et al. 1999). LHA neurons project widely to a large number of extrahypothalamic areas. Major targets of the $\mathrm{MCH}$ and $\mathrm{OX}$ neurons include the brainstem motor systems, sympathetic and parasympathetic preganglionic nuclei in the medulla and spinal cord, the locus coeruleus, the medial raphe nucleus, the tuberomammillary nucleus and the cerebral cortex. All these areas are fundamental in different aspects of food intake regulation, from feeding-related behaviours to arousal and motor activity (Willie et al. 2001; López et al. 2001a, 2005b; Saper et al. 2002; Steininger et al. 2004). Thus, these second-order neurons in the LHA play a fundamental role in integrating information from ARC neurons before sending it to other CNS areas involved in feeding control.

\section{Hypothalamic neuropeptides regulating food intake}

Neuropeptide $Y$. NPY is a thirty-six-amino acid peptide belonging to the PP-fold family of peptides, which also includes PYY and PP (Conlon, 2002). NPY is widely distributed in the CNS and is one of the most potent stimulators of food intake; repeated third ventricle or PVH administration of NPY induces striking hyperphagia and obesity (Stanley et al. 1986; Zarjevski et al. 1993). Central administration of NPY also reduces brown fat thermogenesis (Billington et al. 1991), suppresses sympathetic nerve activity (Egawa et al. 1991) and inhibits the thyroid axis (Fekete et al. 2002) in order to reduce energy expenditure. Additionally, NPY induces hyperinsulinaemia (Moltz \& McDonald, 1985; Zarjevski et al. 1993), hypercorticosteronaemia (Zarjevski et al. 1993) and reduced plasma testosterone levels (Kalra et al. 1999); effects that are independent of increased food intake. NPY mRNA levels and NPY release in the ARC respond to changes in energy status, being increased after fasting and food restriction and decreased after refeeding (Sanacora et al. 1990; Kalra et al. 1991; Swart et al. 2002).

Regardless of its potent orexigenic effect, NPYknock-out mice show normal body weight and adiposity (Erickson et al. 1996), probably related to a compensatory and redundant mechanism in the orexigenic pathways, particularly in relation to AgRP. However, it has been reported recently that selective ablation of AgRP/NPY neurons in adult mice results in hypophagia and leanness, demonstrating direct evidence for a critical role of these neurons in the regulation of energy homeostasis (Gropp et al. 2005; Luquet et al. 2005).

NPY, as part of the PP-fold family of peptides, binds and activates G-protein-coupled receptors termed $\mathrm{Y}_{1}-\mathrm{Y}_{6}$ (Larhammar, 1996; Kalra et al. 1999). $\mathrm{Y}_{1}-\mathrm{Y}_{5}$ receptors are present in rat brain, but $\mathrm{Y}_{6}$ is only active in mice, being absent in rats and inactive in primates (Inui, 1999). The orexigenic action of NPY is thought to be mediated by hypothalamic $\mathrm{Y}_{1}, \mathrm{Y}_{2}, \mathrm{Y}_{4}$ and $\mathrm{Y}_{5}$ receptors (Kalra et al. 1999; Williams G et al. 2000, 2001; Stanley et al. 2005).

Melanocortin system ( $\alpha$-melanocyte-stimulating hormone/ pro-opiomelanocortin and agouti-related peptide). Among the hypothalamic neuropeptide systems that regulate feeding, melanocortins play a prominent role (Kalra et al. 1999; Cone, 1999, 2005; Coll et al. 2004b). The central melanocortin system modulates energy homeostasis through the anorectic actions of the agonist $\alpha$-melanocytestimulating hormone (a POMC cleavage product) and the endogenous orexigenic antagonist AgRP (Kalra et al. 
1999; Cone, 1999, 2005; Coll et al. 2004b). Five melanocortin receptors $(\mathrm{MCnR}, n 1-5)$ have been identified. The feeding-related effects of both $\alpha$-melanocyte-stimulating hormone and AgRP are mediated via MC3R and MC4R. Both receptors are widely expressed in the hypothalamus and are found in the ARC, VMH and PVH (Kalra et al. 1999; Cone, 1999, 2005; Coll et al. 2004b).

Circulating hormones such as insulin (Kim et al. 1999), leptin (Ahima \& Flier, 2000b), ghrelin (Nakazato et al. 2001; Cowley et al. 2003; Seoane et al. 2003), PYY (Batterham et al. 2002), glucocorticoids (Savontaus et al. 2002) and oestrogens (Fodor \& Delemarre-van de Waal, 2001; Tritos et al. 2004) act on melanocortin AgRP and POMC neurons, providing information on energy status from the periphery. Hypothalamic POMC mRNA expression is regulated by nutritional status, with low levels during fasting that return to normal after leptin treatment or refeeding (Schwartz et al. 1997; Swart et al. 2002). In contrast, AgRP mRNA expression is increased by fasting, but unlike NPY mRNA levels, which are decreased after refeeding, AgRP levels remain elevated (Swart et al. 2002). Recent evidence also suggests that circulating macronutrients, such as glucose (Sergeyev et al. 2000; Fraley et al. 2002; Ibrahim et al. 2003) and lipids (Obici et al. 2002b; Morgan et al. 2004) modulate AgRP and POMC neurons.

The role of melanocortin signalling in body-weight homeostasis is fully supported by the phenotype of transgenic and knock-out mice, as well as identified human mutations. Transgenic mice over-expressing AgRP are obese (Ollmann et al. 1997) and reduction of hypothalamic AgRP by RNA interference reduces body weight (Makimura et al. 2002). However, AgRP-knock-out mice (as well as the double knock-out AgRP/NPY) show normal body weight and food intake (Qian et al. 2002), while selective ablation of AgRP/NPY neurons in adult mice results in hypophagia and leanness (Gropp et al. 2005; Luquet et al. 2005). The role of AgRP in human obesity is not well defined, but a polymorphism in the human agrp gene in man is associated with reduced body weight and fat mass (Marks et al. 2004). POMC-knock-out mice (Yaswen et al. 1999; Challis et al. 2004; Coll et al. 2005) and hucman (Krude et al. 1998) are hyperphagic and obese and display adrenal insufficiency. MC4R-knock-out mice (Huszar et al. 1997; Fan et al. 1997) and hucman (Yeo et al. 1998; Farooqi et al. 2000, 2003) also show hyperphagia and obesity. Finally, MC3R-knock-out mice display an increase in adiposity (Butler et al. 2000).

Melanin-concentrating hormone. $\mathrm{MCH}$ is an orexigenic neuropeptide expressed in the LHA-perifornical area. Central administration of $\mathrm{MCH}$ increases food intake and adiposity in rats and mice (Qu et al. 1996; Marsh et al. 2002). $\mathrm{MCH}$ receptor 1 antagonists inhibit food intake and induce weight loss (Borowsky et al. 2002). MCH expression is regulated by nutritional status; fasting induces $\mathrm{MCH}$ mRNA expression and leptin decreases it (Qu et al. 1996; Tritos et al. 2001).

The important role of $\mathrm{MCH}$ in appetite regulation is supported by the phenotype of GM models. Transgenic mice over-expressing $\mathrm{MCH}$ display hyperphagia and obesity (Ludwig et al. 2001; Marsh et al. 2002), while
$\mathrm{MCH}-k n o c k-o u t$ mice are hypophagic and lean (Shimada et al. 1998). Finally, the double knock-outs leptin/MCH have lower weight gain and adiposity compared with leptin-deficient $o b / o b$ mice (Segal-Lieberman et al. 2003), suggesting that $\mathrm{MCH}$ is a downstream mediator of leptin effects on feeding. Finally, $\mathrm{MCH}$ receptor1-knock-out mice display a lean phenotype as a result of increased energy expenditure (Marsh et al. 2002).

Orexins. The OX (OX-A and OX-B), or hypocretins (hypocretins 1 and 2), are neuropeptides derived from the common precursor prepro-OX (also called preprohyprocretin) expressed in the LHA/perifornical area (de Lecea et al. 1998; Sakurai et al. 1998). Two different OX receptors have been cloned, termed OX 1 receptor (or hypocretin receptor 1) OX 2 receptor (or hypocretin receptor 2). Although OX expression in the brain is only located in the LHA-perifornical area (Broberger et al. 1998a; Elias et al. 1998b; Horvath et al. 1999), OX receptors show a widespread distribution in the CNS, with high levels of abundance in some hypothalamic nuclei (ARC, DMH, LHA, PVH and VMH; Marcus et al. 2001; Backberg et al. 2002). OX receptors are also present in the adrenal gland (López et al. 1999), pituitary (Blanco et al. 2001) gut (Kirchgessner \& Liu, 1999), testis, kidney, ovary and placenta (Johren et al. 2001).

$\mathrm{OX}$ are important regulators of the sleep-wake cycle and the absence of OX signalling causes narcolepsy (Willie et al. 2001; Taheri et al. 2002; Sutcliffe \& de Lecea, 2002). However, evidence also links OX to endocrine function (López et al. 1999, 2001b, 2004, 2005b; Barreiro et al. 2004; Seoane et al. 2004) and food intake regulation (Sakurai et al. 1998; López et al. 2001a, $2005 \mathrm{~b}$ ). Central administration of OX to rats stimulates feeding via a NPY-dependent mechanism (Sakurai et al. 1998; Dube et al. 2000; Ida et al. 2000; Jain et al. 2000; Yamanaka et al. 2000; López et al. 2002). Other evidence has linked the feeding actions of OX-A to opioids, corticotrophin-releasing hormone (Ida et al. 2000), urocortin and melanocortins (Wang \& Kotz, 2002). Finally, prepro-OX-knock-out mice (Willie et al. 2001) and the OX/ataxin-3 transgenic mice in which OXcontaining neurons are ablated (Hara et al. 2001) are hypophagic.

OX neurons are also responsive to peripheral signals regulating food intake. The expression of prepro-OX is increased in fasting and restored to normal by leptin (Sakurai et al. 1998; López et al. 2000; Zhu et al. 2002; Yamanaka et al. 2003). OX neurons in the lateral hypothalamus are also sensitive to glucose, being activated during hypoglycaemia (Cai et al. 1999; Griffond et al. 1999; Moriguchi et al. 1999). It has been also proposed that visceral feeding-related signals regulate OX actions, which are thought to act via the vagus nerve and the NTS. Thus, stimuli acting as 'terminate-eating' signals, such as gastric distension and glucose concentrations in the portal vein, appear to be important in the regulation of OX (Cai et al. 2001, 2002).

Despite evidence supporting the orexigenic effect of OX, it has been proposed (Hagan et al. 1999) that these effects are secondary, and are related to the state of arousal and vigilance necessary for normal feeding. However, 


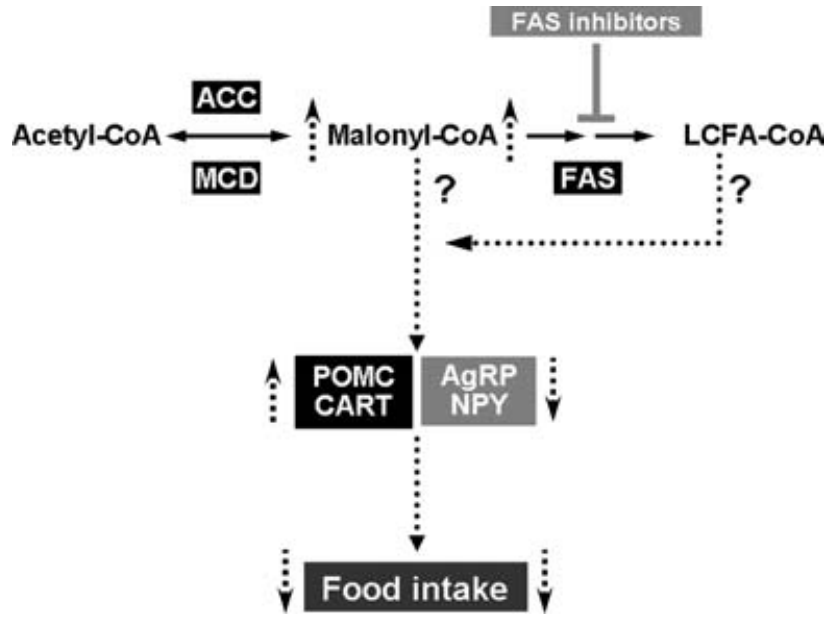

Fig. 2. Fatty acid synthesis pathway. Fatty acid synthesis is catalysed by acetyl-Co A carboxylase (ACC) and fatty acid synthase (FAS) in the cytoplasm. ACC catalyses the carboxylation of acetylCoA to malonyl-CoA. Acetyl-CoA and malonyl-CoA can be used as the substrates for the production of palmitate by the seven enzymic reactions catalysed by FAS. The synthesis step of malonyl-CoA is a reversible regulated mechanism, and malonyl-CoA decarboxylase (MCD) converts malonyl-CoA back to acetyl-CoA. The inhibition $(\perp)$ of FAS (by using cerulenin, C75 or tamoxifen) increases the levels of malonyl-CoA in the hypothalamus, altering the concentration of long-chain fatty acid (LCFA)-CoA, which reduces feeding. The link between this effect and the neuropeptide changes is unknown (?). POMC, pro-opiomelanocortin; CART, cocaine- and amphetamineregulated transcript; AgRP, agouti-related peptide; NPY, neuropeptide $\mathrm{Y}$.

OX-A-induced feeding that is independent of arousal activation has been reported (Kotz et al. 2002).

Cocaine- and amphetamine-regulated transcript. CART is the third-most-abundant transcript in the hypothalamus and is expressed in the ARC, DMH, LHA and PVH (Kristensen et al. 1998; Elias et al. 2001; Hunter et al. 2004). Food deprivation decreases ARC expression of CART, while peripheral leptin treatment in $o b / o b$ mice increases CART expression (Kristensen et al. 1998). Central administration of CART-(1-102) and CART-(82-103) inhibits feeding (Kristensen et al. 1998) and CART-knockout mice display a predisposition to become obese on a high-fat diet (Asnicar et al. 2001), an age-related increase in body weight and impaired glucose metabolism (Wierup et al. 2005), supporting the role of CART in the hypothalamic mechanism regulating food intake.

\section{Lipid sensing in the hypothalamus}

Although circulating lipids have for some time been hypothesised as signalling molecules that inform the hypothalamus of metabolic status, this function has only recently been definitively demonstrated. Following an elegant experimental approach Rossetti and colleagues (Obici et al. 2002b; Morgan et al. 2004) have shown that central administration of long-chain fatty acids such as oleic acid inhibits food intake via AgRP/NPY neurons in the ARC; this effect is not produced by medium-chain fatty acids. The physiological relevance of these data is intriguing. Since circulating NEFA can access the brain it is likely that the anorectic action of long-chain fatty acids may play an important role in the regulation of energy balance by acting as a 'nutrient abundance' signal (Lam et al. 2005a,b). Impairment of hypothalamic lipid-sensing in rats induces obesity (He et al. 2006), as well alterations in plasma glucose (Pocai et al. 2006), indicating that this mechanism may be important in the physiological regulation of metabolism and body-weight homeostasis.

\section{Fatty acid synthesis pathway in the hypothalamus}

Recent reports demonstrate that the enzymes of the fatty acid synthesis pathway (Fig. 2) are expressed in the hypothalamus. Acetyl-CoA carboxylase, FAS and malonylCoA decarboxylase mRNA and proteins have been detected in the ARC, DMH, PVH and VMH (Kim et al. 2002; López et al. 2006). The anatomical location of these enzymes suggests that they may play a role in the hypothalamic mechanism regulating feeding. This notion is further supported by evidence demonstrating that peripheral and central administration of the FAS inhibitors cerulenin, C75 and tamoxifen reduces food intake and body weight through a malonyl-CoA-dependent mechanism (Loftus et al. 2000; Hu et al. 2003; Lelliott et al. 2005; López et al. 2006). The anorectic action of FAS inhibitors is linked to decreased expression of AgRP/NPY and elevated expression of CART/POMC in the neurons of the ARC, although the molecular mechanisms of this interaction have not yet been completely defined (Loftus et al. 2000; Shimokawa et al. 2002; López et al. 2006). Additionally, it has been demonstrated that nutritional status regulates hypothalamic malonyl-CoA levels and FAS expression in a nucleus-specific manner, with FAS mRNA levels down regulated by fasting and up regulated by refeeding, an effect specific to the VMH (Fig. 3; López et al. 2006). This evidence suggests that the regulation of FAS could be a physiological mechanism of food-intake control and that the increase in malonyl-CoA induced by FAS inhibition may act as central lipidsensing signal.

\section{Brainstem regulation of food intake}

The brainstem plays an essential role in the regulation of body-weight homeostasis. The NTS is anatomically close to the area postrema, a circumventricular organ, like the ARC, with a partial BBB (Stanley et al. 2005). Consequently, the NTS is in a perfect location to receive peripheral circulating signals, as well as vagal afferents from the gastrointestinal tract and the glossopharyngeal nerves (Kalia \& Sullivan, 1982; Sawchenko, 1983).

The NTS contains GLP-1, NPY and melanocortin neuronal circuits. GLP-1-expressing neurons comprise the main brainstem circuit modulating feeding. In the CNS GLP-1 is only synthesised in the caudal NTS. GLP-1 fibres project to the PVH and DMH, with fewer projections to the ARC (Stanley et al. 2005). Central administration of GLP-1 into either the third ventricle or the fourth ventricle reduces food intake, and treatment with the GLP-1 receptor 
(a)

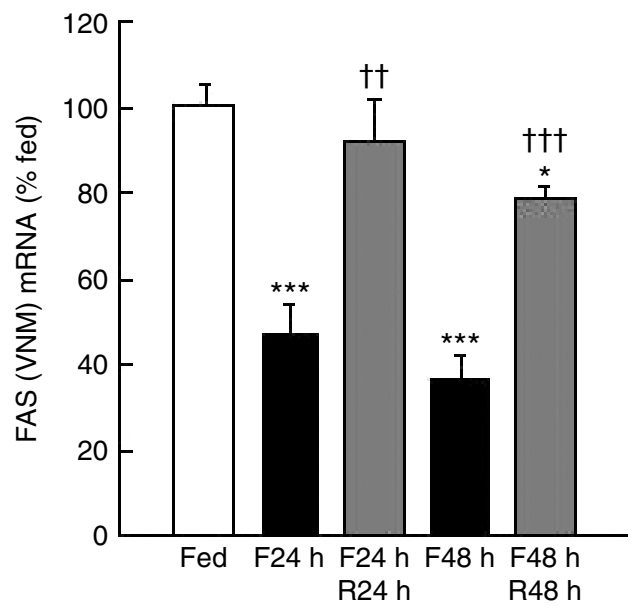

(c)

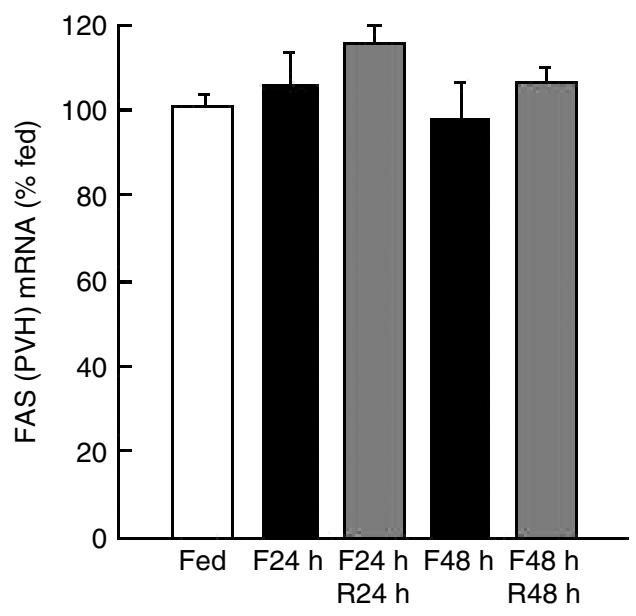

(b)

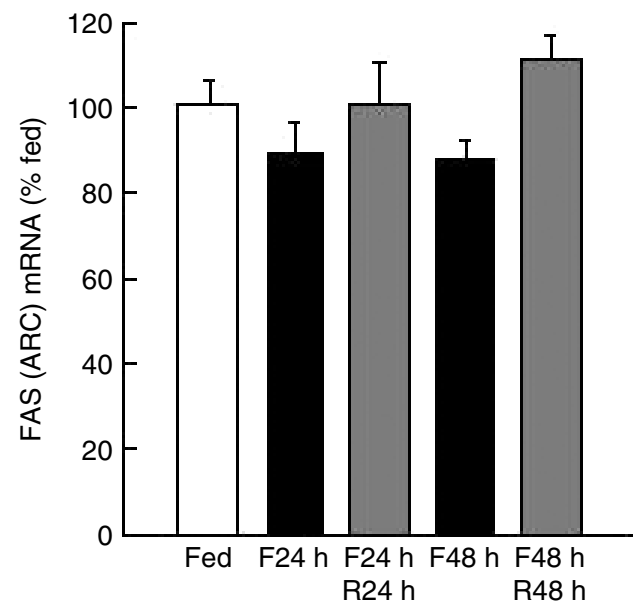

(d)

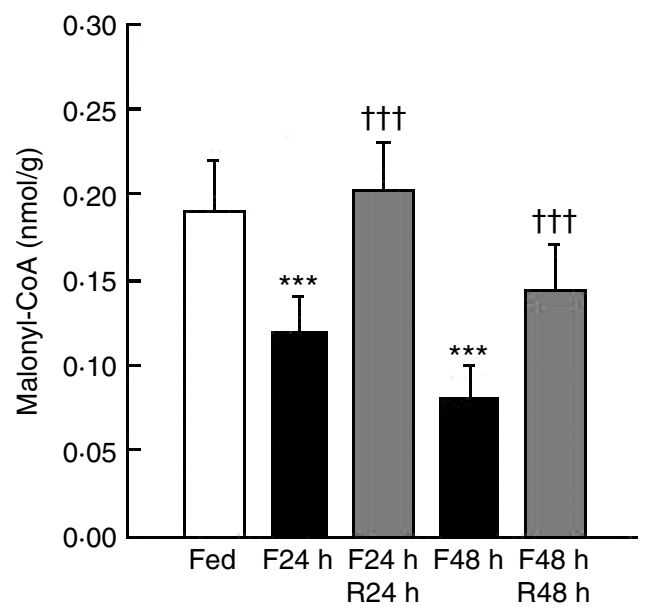

Fig. 3. Fatty acid synthase (FAS) expression and malonyl-CoA levels are nutritionally regulated in the rat hypothalamus. Expression of FAS in the ventromedial nucleus of the hypothalamus (VMH; a), arcuate nucleus (ARC; b) and paraventricular nucleus ( $\mathrm{PVH} ; \mathrm{c})$, and malonyl-CoA levels (d) of fed rats $(\square)$, fasted $(F ; \boldsymbol{\square})$ rats and $F+$ refed $(R ; \square)$ rats. Values are means with their standard errors represented by vertical bars. Mean values were significantly different from those for fed rats: ${ }^{\star} P<0.05,{ }^{* * *} P<0.001$. Mean values were significantly different from those for the corresponding $\mathrm{F}$ rats: $\dagger \dagger P<0.01$, $\dagger \dagger \dagger P<0.001$.

antagonist exendin (9-39) increases appetite (Turton et al. 1996). This finding suggests a role for endogenous GLP-1 in energy homeostasis. NPY neurons from the brainstem project to the PVH (Sawchenko et al. 1985), and extracellular NPY levels within the NTS are nutritionallyregulated (Yoshihara et al. 1996). $\mathrm{Y}_{1}$ and $\mathrm{Y}_{5}$ receptors are also located in the NTS (Harfstrand et al. 1986; Dumont et al. 1998; Glass et al. 2002). POMC-derived peptides are synthesised in the NTS of the rat (Kawai et al. 1984; Bronstein et al. 1992; Fodor et al. 1996). Brainstem POMC neurons are activated by feeding and also by CCK treatment (Fan et al. 1997). MC4R are also expressed in the NTS (Mountjoy et al. 1994) and act to modulate energy intake. Fourth-ventricle administration of a MC3R/MC4R agonist decreases food intake, and MC3R/MC4R-antagonist administration to these areas increases food intake (Williams DL et al. 2000).
Prolactin-releasing peptide is expressed in the NTS, in addition to the hypothalamic DMH (Lee et al. 2000). Prolactin-releasing peptide expression is reduced in fasting, and central administration of prolactin-releasing peptide decreases appetite by a corticotrophin-releasing hormone- and CCK-mediated mechanism (Seal et al. 2001; Ellacott et al. 2002; Lawrence et al. 2004). Chronic administration of prolactin-releasing peptide does not affect food intake (Ellacott et al. 2003), suggesting a role in short-term appetite regulation instead of long-term control of body weight.

\section{Reward and regulation of food intake}

Even in the absence of an energy deficit, the rewarding nature of food may act as a stimulus to feeding. Several signals are able to modulate reward pathways. 
The reward circuitry is complex, involving interactions between several signalling systems, including the opioid, dopaminergic and endocannabinoid (EC) systems (Cota et al. 2003a,b; Flier, 2004; Di Marzo \& Matias, 2005; Lichtman \& Cravatt, 2005; Fulton et al. 2006; Hommel et al. 2006).

Opioids. Opioids play an important role in the regulation of feeding. The anatomical site for opioid action is the nucleus accumbens (Zhang \& Kelley 2000; Zhang et al. 2003). Mice lacking enkephalin or $\beta$-endorphin lose the reinforcing property of food, despite the palatability. This effect is overridden after fasting, indicating that homeostatic mechanisms can overrule the hedonistic pathway (Hayward et al. 2002). In man opiate antagonists decrease food palatability without altering subjective hunger (Yeomans et al. 1990; Drewnowski et al. 1992).

Endocannabinoids. The effect of marijuana (Cannabis sativa) to increase appetite has been known for many years (Di Marzo \& Matias, 2005; Lichtman \& Cravatt, 2005). The primary constituent of cannabis is $\Delta^{9}$ tetrahydrocannabinol; this molecule, along with other naturallyoccurring and synthetic cannabinoids (CB), binds to two separate G-protein-coupled receptors: the CB1 receptor, which is located in the CNS and periphery; the CB2 receptor, which is primarily found in cells of the immune system (Matsuda et al. 1990; Devane et al. 1992; Munro et al. 1993). These receptors also bind endogenous ligands, the EC, which include the fatty acid amide $\mathrm{N}$-arachidonoyl ethanolamine (anandamide) and the monoacylglycerol 2-arachidonoylglycerol (Di Marzo et al. 2001; Cota et al. 2003a; Di Marzo \& Matias, 2005; Lichtman \& Cravatt, 2005).

Central and peripheral administration of EC stimulates food intake (Williams et al. 1998; Koch, 2001; Cota et al. 2003a). This orexigenic effect is mediated via CB1 receptors in the hypothalamus, which co-localise with CART, corticotrophin-releasing hormone, $\mathrm{MCH}$ and $\mathrm{OX}$ (Cota et al. 2003b). Additionally, CB1-knock-out mice display hypophagia and leanness (Cota et al. 2003b), and leptindeficient signalling is associated with high hypothalamic EC levels (Di Marzo et al. 2001). Recent evidence (Verty et al. 2004) has also shown that the EC receptors are located downstream from the melanocortin system.

Together this evidence supports the important role of the EC system in the regulation of feeding. In fact, there is currently a CB1 selective antagonist, Rimonabant (SR141716), in use in phase III clinical trials that may be a potentially promising anti-obesity drug (Di Marzo \& Matias, 2005).

Dopamine. The dopaminergic system is also important in the rewarding circuitry of feeding regulation (Fulton et al. 2006; Hommel et al. 2006). In fact, mice lacking tyrosine hydroxylase, the enzyme synthesising dopamine, are hypophagic (Szczypka et al. 2001). These actions are mediated via $D_{1}$ and $D_{2}$ receptors (Szczypka et al. 2001).

Serotonin. Serotonin plays an important role in regulating both rewarding and homeostatic mechanisms (Halford \& Blundell, 2000b). Serotonin actions of food intake are mediated via the melanocortin system (Heisler et al. 2002, 2003). In fact, the currently-discontinued anorectic agent fenfluramine mediates its actions via serotonin and melanocortins (Heisler et al. 2002).

\section{Conclusions}

Multiple, redundant and complex peripheral neural circuits participate in the regulation of food intake and bodyweight homeostasis. All this evidence indicates that obesity, and associated metabolic alterations, is complex, multifactorial and chronic pathology. Thus, the search for, and development of, new weight-loss drugs is made extremely complicated. In fact, the efficacy of drugs acting on a single molecular target might be limited by compensatory feedback mechanism. In the near future combined therapies that act on both peripheral and central targets should be sought. Understanding these molecular networks regulating food intake could lead to the design of better therapeutic targets for weight loss.

\section{Acknowledgements}

This work has been supported by grants from Instituto Salud Carlos III, Spanish Ministry of Health, Xunta de Galicia, DGICYT (BFU 2005-06287) and the European Union (LSHM-CT-2003-503041 and QLK6-2001-02288). CD and ML are members of the CIBER of Obesity and Nutrition (ISCIII). LMW is funded by the Scottish Executive Environment \& Rural Affairs Department (SEERAD).

\section{References}

Abizaid A, Gao Q \& Horvath TL (2006) Thoughts for food: brain mechanisms and peripheral energy balance. Neuron 51, 691-702.

Ahima RS (2000) Leptin and the neuroendocrinology of fasting. Frontiers in Hormone Research 26, 42-56.

Ahima RS \& Flier JS (2000a) Adipose tissue as an endocrine organ. Trends in Endocrinology and Metabolism 11, 327-332.

Ahima RS \& Flier JS (2000b) Leptin. Annual Review of Physiology 62, 413-437.

Ahima RS, Prabakaran D, Mantzoros C, Qu D, Lowell B, Maratos-Flier E \& Flier JS (1996) Role of leptin in the neuroendocrine response to fasting. Nature 382, 250-252.

Air EL, Strowski MZ, Benoit SC, Conarello SL, Salituro GM, Guan XM, Liu K, Woods SC \& Zhang BB (2002) Small molecule insulin mimetics reduce food intake and body weight and prevent development of obesity. Nature Medicine $\mathbf{8}$, 179-183.

Anand BK \& Brobeck JR (1951) Localization of a 'feeding center' in the hypothalamus of the rat. Proceedings of the Society for Experimental Biology and Medicine 77, 323-324.

Andersson U, Filipsson K, Abbott CR, Woods A, Smith K, Bloom SR, Carling D \& Small CJ (2004) AMP-activated protein kinase plays a role in the control of food intake. Journal of Biological Chemistry 279, 12005-12008.

Arita Y, Kihara S, Ouchi N, Takahashi M, Maeda K, Miyagawa J et al. (1999) Paradoxical decrease of an adipose-specific protein, adiponectin, in obesity. Biochemical and Biophysical Research Communications 257, 79-83.

Ariyasu H, Takaya K, Tagami T, Ogawa Y, Hosoda K, Akamizu T et al. (2001) Stomach is a major source of circulating ghrelin, and feeding state determines plasma ghrelin-like 
immunoreactivity levels in humans. Journal of Clinical Endocrinology and Metabolism 86, 4753-4758.

Arvat E, Di Vito L, Broglio F, Papotti M, Muccioli G, Dieguez C, Casanueva FF, Deghenghi R, Camanni F \& Ghigo E (2000) Preliminary evidence that ghrelin, the natural GH secretagogue (GHS)-receptor ligand, strongly stimulates GH secretion in humans. Journal of Endocrinological Investigation 23, 493-495.

Asakawa A, Inui A, Yuzuriha H, Ueno N, Katsuura G, Fujimiya M, Fujino MA, Niijima A, Meguid MM \& Kasuga M (2003) Characterization of the effects of pancreatic polypeptide in the regulation of energy balance. Gastroenterology 124, 1325-1336.

Asin KE, Gore PA Jr, Bednarz L, Holladay M \& Nadzan AM (1992) Effects of selective CCK receptor agonists on food intake after central or peripheral administration in rats. Brain Research 571, 169-174.

Asnicar MA, Smith DP, Yang DD, Heiman ML, Fox N, Chen YF, Hsiung HM \& Koster A (2001) Absence of cocaineand amphetamine-regulated transcript results in obesity in mice fed a high caloric diet. Endocrinology 142, 4394-4400.

Backberg M, Hervieu G, Wilson S \& Meister B (2002) Orexin receptor-1 (OX-R1) immunoreactivity in chemically identified neurons of the hypothalamus: focus on orexin targets involved in control of food and water intake. European Journal of Neuroscience 15, 315-328.

Badman MK \& Flier JS (2005) The gut and energy balance: visceral allies in the obesity wars. Science 307, 1909-1914.

Bado A, Levasseur S, Attoub S, Kermorgant S, Laigneau JP, Bortoluzzi MN, Moizo L, Lehy T, Guerre-Millo M, MarchandBrustel Y \& Lewin MJ (1998) The stomach is a source of leptin. Nature 394, 790-793.

Banerjee RR, Rangwala SM, Shapiro JS, Rich AS, Rhoades B, Qi Y et al. (2004) Regulation of fasted blood glucose by resistin. Science 303, 1195-1198.

Banks WA (2001a) Enhanced leptin transport across the bloodbrain barrier by alpha1-adrenergic agents. Brain Research $\mathbf{8 9 9}$, 209-217.

Banks WA (2001b) Leptin transport across the blood-brain barrier: implications for the cause and treatment of obesity. Current Pharmaceutical Design 7, 125-133.

Banks WA, Kastin AJ, Huang W, Jaspan JB \& Maness LM (1996) Leptin enters the brain by a saturable system independent of insulin. Peptides 17, 305-311.

Barreiro ML, Gaytan F, Caminos JE, Pinilla L, Casanueva FF, Aguilar E, Dieguez C \& Tena-Sempere M (2002) Cellular location and hormonal regulation of ghrelin expression in rat testis. Biology of Reproduction 67, 1768-1776.

Barreiro ML, Pineda R, Navarro VM, López M, Suominen JS, Pinilla L, Senarís R, Toppari J, Aguilar E, Diéguez C \& TenaSempere M (2004) Orexin 1 receptor messenger ribonucleic acid expression and stimulation of testosterone secretion by orexin-a in rat testis. Endocrinology 145, 2297-2306.

Batterham RL, Cowley MA, Small CJ, Herzog H, Cohen MA, Dakin CL et al. (2002) Gut hormone PYY(3-36) physiologically inhibits food intake. Nature 418, 650-654.

Batterham RL, Le Roux CW, Cohen MA, Park AJ, Ellis SM, Patterson M, Frost GS, Ghatei MA \& Bloom SR (2003) Pancreatic polypeptide reduces appetite and food intake in humans. Journal of Clinical Endocrinology and Metabolism 88, 3989-3992.

Beglinger C, Degen L, Matzinger D, D'Amato M \& Drewe J (2001) Loxiglumide, a CCK-A receptor antagonist, stimulates calorie intake and hunger feelings in humans. American Journal of Physiology 280, R1149-R1154.

Bellinger LL \& Bernardis LL (2002) The dorsomedial hypothalamic nucleus and its role in ingestive behavior and body weight regulation: lessons learned from lesioning studies. Physiology and Behavior 76, 431-442.
Benoit SC, Air EL, Coolen LM, Strauss R, Jackman A, Clegg DJ, Seeley RJ \& Woods SC (2002) The catabolic action of insulin in the brain is mediated by melanocortins. Journal of Neuroscience 22, 9048-9052.

Berg AH, Combs TP, Du X, Brownlee M \& Scherer PE (2001) The adipocyte-secreted protein Acrp30 enhances hepatic insulin action. Nature Medicine 7, 947-953.

Berg AH, Combs TP \& Scherer PE (2002) ACRP30/adiponectin: an adipokine regulating glucose and lipid metabolism. Trends in Endocrinology and Metabolism 13, 84-89.

Bernardis LL \& Bellinger LL (1996) The lateral hypothalamic area revisited: ingestive behavior. Neuroscience and Biobehavioral Reviews 20, 189-287.

Berthoud HR, Jedrzejewska A \& Powley TL (1990) Simultaneous labeling of vagal innervation of the gut and afferent projections from the visceral forebrain with dil injected into the dorsal vagal complex in the rat. Journal of Comparative Neurology 301, 65-79.

Bi S, Ladenheim EE, Schwartz GJ \& Moran TH (2001) A role for NPY overexpression in the dorsomedial hypothalamus in hyperphagia and obesity of OLETF rats. American Journal of Physiology 281, R254-R260.

Billington CJ, Briggs JE, Grace M \& Levine AS (1991) Effects of intracerebroventricular injection of neuropeptide $\mathrm{Y}$ on energy metabolism. American Journal of Physiology 260, R321-R327.

Blanco M, López M, García-Caballero T, Gallego R, VázquezBoquete A, Morel G, Señaris RM, Casanueva F, Diéguez C \& Beiras A (2001) Cellular localization of orexin receptors in human pituitary. Journal of Clinical Endocrinology and Metabolism 86, 1616-1619.

Borowsky B, Durkin MM, Ogozalek K, Marzabadi MR, DeLeon J, Lagu B et al. (2002) Antidepressant, anxiolytic and anorectic effects of a melanin-concentrating hormone-1 receptor antagonist. Nature Medicine 8, 825-830.

Bouret SG, Draper SJ \& Simerly RB (2004a) Formation of projection pathways from the arcuate nucleus of the hypothalamus to hypothalamic regions implicated in the neural control of feeding behavior in mice. Journal of Neuroscience 24, 2797 2805.

Bouret SG, Draper SJ \& Simerly RB (2004b) Trophic action of leptin on hypothalamic neurons that regulate feeding. Science 304, 108-110.

Bouret SG \& Simerly RB (2004) Leptin and development of hypothalamic feeding circuits. Endocrinology 145, 2621-2626.

Bray GA (2000) Afferent signals regulating food intake. Proceedings of the Nutrition Society 59, 373-384.

Broberger C, de Lecea L, Sutcliffe JG \& Hokfelt T (1998a) Hypocretin/orexin- and melanin-concentrating hormoneexpressing cells form distinct populations in the rodent lateral hypothalamus: relationship to the neuropeptide $\mathrm{Y}$ and agouti gene-related protein systems. Journal of Comparative Neurology 402, 460-474.

Broberger C, Johansen J, Johansson C, Schalling M \& Hokfelt T (1998b) The neuropeptide Y/agouti gene-related protein (AGRP) brain circuitry in normal, anorectic, and monosodium glutamate-treated mice. Proceedings of the National Academy of Sciences USA 95, 15043-15048.

Broberger C, Landry M, Wong H, Walsh JN \& Hokfelt T (1997) Subtypes Y1 and Y2 of the neuropeptide $\mathrm{Y}$ receptor are respectively expressed in pro-opiomelanocortin- and neuropeptide-Y-containing neurons of the rat hypothalamic arcuate nucleus. Neuroendocrinology 66, 393-408.

Bronstein DM, Schafer MK, Watson SJ \& Akil H (1992) Evidence that beta-endorphin is synthesized in cells in the nucleus tractus solitarius: detection of POMC mRNA. Brain Research 587, 269-275. 
Bruning JC, Gautam D, Burks DJ, Gillette J, Schubert M, Orban PC, Klein R, Krone W, Muller-Wieland D \& Kahn CR (2000) Role of brain insulin receptor in control of body weight and reproduction. Science 289, 2122-2125.

Bullock BP, Heller RS \& Habener JF (1996) Tissue distribution of messenger ribonucleic acid encoding the rat glucagon-like peptide-1 receptor. Endocrinology 137, 2968-2978.

Burguera B, Couce ME, Curran GL, Jensen MD, Lloyd RV, Cleary MP \& Poduslo JF (2000) Obesity is associated with a decreased leptin transport across the blood-brain barrier in rats. Diabetes 49, 1219-1223.

Butler AA, Kesterson RA, Khong K, Cullen MJ, Pelleymounter MA, Dekoning J, Baetscher M \& Cone RD (2000) A unique metabolic syndrome causes obesity in the melanocortin-3 receptor-deficient mouse. Endocrinology 141, 3518-3521.

Cai XJ, Evans ML, Lister CA, Leslie RA, Arch JR, Wilson S \& Williams G (2001) Hypoglycemia activates orexin neurons and selectively increases hypothalamic orexin-B levels: responses inhibited by feeding and possibly mediated by the nucleus of the solitary tract. Diabetes 50, 105-112.

Cai XJ, Liu XH, Evans M, Clapham JC, Wilson S, Arch JR, Morris R \& Williams G (2002) Orexins and feeding: special occasions or everyday occurrence? Regulatory Peptides 104, $1-9$.

Cai XJ, Widdowson PS, Harrold J, Wilson S, Buckingham RE, Arch JR, Tadayyon M, Clapham JC, Wilding J \& Williams G (1999) Hypothalamic orexin expression: modulation by blood glucose and feeding. Diabetes 48, 2132-2137.

Calle EE \& Kaaks R (2004) Overweight, obesity and cancer: epidemiological evidence and proposed mechanisms. Nature Reviews Cancer 4, 579-591.

Caminos JE, Nogueiras R, Blanco M, Seoane LM, Bravo S, Alvarez CV, García-Caballero T, Casanueva FF \& Dieguez C (2003a) Cellular distribution and regulation of ghrelin messenger ribonucleic acid in the rat pituitary gland. Endocrinology 144, 5089-5097.

Caminos JE, Nogueiras R, Gallego R, Bravo S, Tovar S, GarcíaCaballero T, Casanueva FF \& Diéguez C (2005) Expression and regulation of adiponectin and receptor in human and rat placenta. Journal of Clinical Endocrinology and Metabolism 90, 4276-4286.

Caminos JE, Tena-Sempere M, Gaytan F, Sanchez-Criado JE, Barreiro ML, Nogueiras R, Casanueva FF, Aguilar E \& Dieguez C (2003b) Expression of ghrelin in the cyclic and pregnant rat ovary. Endocrinology 144, 1594-1602.

Campfield LA, Smith FJ \& Burn P (1996) The OB protein (leptin) pathway - a link between adipose tissue mass and central neural networks. Hormone and Metabolic Research 28, 619-632.

Campfield LA, Smith FJ, Guisez Y, Devos R \& Burn P (1995) Recombinant mouse OB protein: evidence for a peripheral signal linking adiposity and central neural networks. Science 269, 546-549.

Casanueva FF \& Diéguez C (1999) Neuroendocrine regulation and actions of leptin. Frontiers in Neuroendocrinology 20, 317-363.

Challis BG, Coll AP, Yeo GS, Pinnock SB, Dickson SL, Thresher RR et al. (2004) Mice lacking pro-opiomelanocortin are sensitive to high-fat feeding but respond normally to the acute anorectic effects of peptide-YY(3-36). Proceedings of the National Academy of Sciences USA 101, 4695-4700.

Challis BG, Pinnock SB, Coll AP, Carter RN, Dickson SL \& O'Rahilly S (2003) Acute effects of PYY3-36 on food intake and hypothalamic neuropeptide expression in the mouse. Biochemical and Biophysical Research Communications 311, 915-919.

Chen H, Charlat O, Tartaglia LA, Woolf EA, Weng X, Ellis SJ et al. (1996) Evidence that the diabetes gene encodes the leptin receptor: identification of a mutation in the leptin receptor gene in $\mathrm{db} / \mathrm{db}$ mice. Cell 84, 491-495.

Chen HY, Trumbauer ME, Chen AS, Weingarth DT, Adams JR, Frazier EG et al. (2004) Orexigenic action of peripheral ghrelin is mediated by neuropeptide Y (NPY) and Agouti-related protein (AgRP). Endocrinology 145, 2607-2612.

Cheung CC, Clifton DK \& Steiner RA (1997) Proopiomelanocortin neurons are direct targets for leptin in the hypothalamus. Endocrinology 138, 4489-4492.

Chou TC, Lee CE, Lu J, Elmquist JK, Hara J, Willie JT et al. (2001) Orexin (hypocretin) neurons contain dynorphin. Journal of Neuroscience 21, RC168.

Chua SC Jr, Koutras IK, Han L, Liu SM, Kay J, Young SJ, Chung WK \& Leibel RL (1997) Fine structure of the murine leptin receptor gene: splice site suppression is required to form two alternatively spliced transcripts. Genomics 45, 264-270.

Clark JT, Kalra PS, Crowley WR \& Kalra SP (1984) Neuropeptide $\mathrm{Y}$ and human pancreatic polypeptide stimulate feeding behavior in rats. Endocrinology 115, 427-429.

Clark JT, Sahu A, Kalra PS, Balasubramaniam A \& Kalra SP (1987) Neuropeptide Y (NPY)-induced feeding behavior in female rats: comparison with human NPY ([Met17]NPY), NPY analog ([norLeu4]NPY) and peptide YY. Regulatory Peptides 17, 31-39.

Clement K, Vaisse C, Lahlou N, Cabrol S, Pelloux V, Cassuto D et al. (1998) A mutation in the human leptin receptor gene causes obesity and pituitary dysfunction. Nature 392, 398-401.

Clement K, Vega N, Laville M, Pelloux V, Guy-Grand B, Basdevant A \& Vidal H (2002) Adipose tissue gene expression in patients with a loss of function mutation in the leptin receptor. International Journal of Obesity and Related Metabolic Disorders 26, 1533-1538.

Coll AP, Challis BG, López M, Piper S, Yeo GS \& O'Rahilly S (2005) Proopiomelanocortin-deficient mice are hypersensitive to the adverse metabolic effects of glucocorticoids. Diabetes 54, 2269-2276.

Coll AP, Challis BG \& O'Rahilly S (2004a) Peptide YY3-36 and satiety: clarity or confusion? Endocrinology 145, 2582-2584.

Coll AP, Farooqi IS, Challis BG, Yeo GS \& O'Rahilly S (2004b) Proopiomelanocortin and energy balance: insights from human and murine genetics. Journal of Clinical Endocrinology and Metabolism 89, 2557-2562.

Cone RD (1999) The central melanocortin system and energy homeostasis. Trends in Endocrinology and Metabolism 10, 211-216.

Cone RD (2005) Anatomy and regulation of the central melanocortin system. Nature Neuroscience 8, 571-578.

Conlon JM (2002) The origin and evolution of peptide YY (PYY) and pancreatic polypeptide (PP). Peptides 23, 269-278.

Considine RV, Sinha MK, Heiman ML, Kriauciunas A, Stephens TW, Nyce MR, Ohannesian JP, Marco CC, McKee LJ \& Bauer TL (1996) Serum immunoreactive-leptin concentrations in normal-weight and obese humans. New England Journal of Medicine 334, 292-295.

Corp ES, Woods SC, Porte D Jr, Dorsa DM, Figlewicz DP \& Baskin DG (1986) Localization of 125I-insulin binding sites in the rat hypothalamus by quantitative autoradiography. Neuroscience Letters 70, 17-22.

Corpa ES, McQuade J, Krasnicki S \& Conze DB (2001) Feeding after fourth ventricular administration of neuropeptide Y receptor agonists in rats. Peptides 22, 493-499.

Cota D, Marsicano G, Lutz B, Vicennati V, Stalla GK, Pasquali R \& Pagotto U (2003a) Endogenous cannabinoid system as a modulator of food intake. International Journal of Obesity and Related Metabolic Disorders 27, 289-301.

Cota D, Marsicano G, Tschop M, Grubler Y, Flachskamm C, Schubert M et al. (2003b) The endogenous cannabinoid 
system affects energy balance via central orexigenic drive and peripheral lipogenesis. Journal of Clinical Investigation 112, 423-431.

Cowley MA, Pronchuk N, Fan W, Dinulescu DM, Colmers WF \& Cone RD (1999) Integration of NPY, AGRP, and melanocortin signals in the hypothalamic paraventricular nucleus: evidence of a cellular basis for the adipostat. Neuron 24, 155-163.

Cowley MA, Smith RG, Diano S, Tschop M, Pronchuk N, Grove KL et al. (2003) The distribution and mechanism of action of ghrelin in the CNS demonstrates a novel hypothalamic circuit regulating energy homeostasis. Neuron 37, 649-661.

Cummings DE, Clement K, Purnell JQ, Vaisse C, Foster KE, Frayo RS, Schwartz MW, Basdevant A \& Weigle DS (2002a) Elevated plasma ghrelin levels in Prader Willi syndrome. Nature Medicine 8, 643-644.

Cummings DE, Frayo RS, Marmonier C, Aubert R \& Chapelot D (2004) Plasma ghrelin levels and hunger scores in humans initiating meals voluntarily without time- and food-related cues. American Journal of Physiology 287, E297-E304.

Cummings DE, Purnell JQ, Frayo RS, Schmidova K, Wisse BE \& Weigle DS (2001) A preprandial rise in plasma ghrelin levels suggests a role in meal initiation in humans. Diabetes 50, $1714-1719$.

Cummings DE \& Shannon MH (2003) Roles for ghrelin in the regulation of appetite and body weight. Archives of Surgery 138, 389-396.

Cummings DE, Weigle DS, Frayo RS, Breen PA, Ma MK, Dellinger EP \& Purnell JQ (2002b) Plasma ghrelin levels after diet-induced weight loss or gastric bypass surgery. New England Journal of Medicine 346, 1623-1630.

Dakin CL, Small CJ, Batterham RL, Neary NM, Cohen MA, Patterson M, Ghatei MA \& Bloom SR (2004) Peripheral oxyntomodulin reduces food intake and body weight gain in rats. Endocrinology 145, 2687-2695.

Date Y, Kojima M, Hosoda H, Sawaguchi A, Mondal MS, Suganuma T, Matsukura S, Kangawa K \& Nakazato M (2000) Ghrelin, a novel growth hormone-releasing acylated peptide, is synthesized in a distinct endocrine cell type in the gastrointestinal tracts of rats and humans. Endocrinology 141, 42554261.

de Lecea L, Kilduff TS, Peyron C, Gao X, Foye PE, Danielson PE et al. (1998) The hypocretins: hypothalamus-specific peptides with neuroexcitatory activity. Proceedings of the National Academy of Sciences USA 95, 322-327.

Devane WA, Hanus L, Breuer A, Pertwee RG, Stevenson LA, Griffin G, Gibson D, Mandelbaum A, Etinger A \& Mechoulam $\mathrm{R}$ (1992) Isolation and structure of a brain constituent that binds to the cannabinoid receptor. Science 258, 1946-1949.

Dhillon H, Zigman JM, Ye C, Lee CE, McGovern RA, Tang V et al. (2006) Leptin directly activates SF1 neurons in the VMH, and this action by leptin is required for normal body-weight homeostasis. Neuron 49, 191-203.

Di Marzo V, Goparaju SK, Wang L, Liu J, Batkai S, Jarai Z, Fezza F, Miura GI, Palmiter RD, Sugiura T \& Kunos G (2001) Leptin-regulated endocannabinoids are involved in maintaining food intake. Nature 410, 822-825.

Di Marzo V \& Matias I (2005) Endocannabinoid control of food intake and energy balance. Nature Neuroscience 8, 585-589.

Drewnowski A, Krahn DD, Demitrack MA, Nairn K \& Gosnell BA (1992) Taste responses and preferences for sweet high-fat foods: evidence for opioid involvement. Physiology and Behavior 51, 371-379.

Dube MG, Horvath TL, Kalra PS \& Kalra SP (2000) Evidence of NPY Y5 receptor involvement in food intake elicited by orexin A in sated rats. Peptides 21, 1557-1560.
Dumont Y, Fournier A \& Quirion R (1998) Expression and characterization of the neuropeptide Y Y5 receptor subtype in the rat brain. Journal of Neuroscience 18, 5565-5574.

Egawa M, Yoshimatsu H \& Bray GA (1991) Neuropeptide Y suppresses sympathetic activity to interscapular brown adipose tissue in rats. American Journal of Physiology 260, R328R334.

El Haschimi K, Pierroz DD, Hileman SM, Bjorbaek C \& Flier JS (2000) Two defects contribute to hypothalamic leptin resistance in mice with diet-induced obesity. Journal of Clinical Investigation 105, 1827-1832.

Elias CF, Aschkenasi C, Lee C, Kelly J, Ahima RS, Bjorbaek C, Flier JS, Saper CB \& Elmquist JK (1999) Leptin differentially regulates NPY and POMC neurons projecting to the lateral hypothalamic area. Neuron 23, 775-786.

Elias CF, Lee C, Kelly J, Aschkenasi C, Ahima RS, Couceyro PR, Kuhar MJ, Saper CB \& Elmquist JK (1998a) Leptin activates hypothalamic CART neurons projecting to the spinal cord. Neuron 21, 1375-1385.

Elias CF, Lee CE, Kelly JF, Ahima RS, Kuhar M, Saper CB \& Elmquist JK (2001) Characterization of CART neurons in the rat and human hypothalamus. Journal of Comparative Neurology 432, 1-19.

Elias CF, Saper CB, Maratos-Flier E, Tritos NA, Lee C, Kelly J et al. (1998b) Chemically defined projections linking the mediobasal hypothalamus and the lateral hypothalamic area. Journal of Comparative Neurology 402, 442-459.

Ellacott KL, Lawrence CB, Pritchard LE \& Luckman SM (2003) Repeated administration of the anorectic factor prolactinreleasing peptide leads to tolerance to its effects on energy homeostasis. American Journal of Physiology 285, R1005R1010.

Ellacott KL, Lawrence CB, Rothwell NJ \& Luckman SM (2002) PRL-releasing peptide interacts with leptin to reduce food intake and body weight. Endocrinology 143, 368-374.

Elmquist JK, Ahima RS, Maratos-Flier E, Flier JS \& Saper CB (1997) Leptin activates neurons in ventrobasal hypothalamus and brainstem. Endocrinology 138, 839-842.

Elmquist JK, Bjorbaek C, Ahima RS, Flier JS \& Saper CB (1998) Distributions of leptin receptor mRNA isoforms in the rat brain. Journal of Comparative Neurology 395, 535-547.

English PJ, Ghatei MA, Malik IA, Bloom SR \& Wilding JP (2002) Food fails to suppress ghrelin levels in obese humans. Journal of Clinical Endocrinology and Metabolism 87, 2984.

Erickson JC, Clegg KE \& Palmiter RD (1996) Sensitivity to leptin and susceptibility to seizures of mice lacking neuropeptide Y. Nature 381, 415-421.

Fan W, Boston BA, Kesterson RA, Hruby VJ \& Cone RD (1997) Role of melanocortinergic neurons in feeding and the agouti obesity syndrome. Nature $\mathbf{3 8 5}, 165-168$.

Farooqi IS, Jebb SA, Langmack G, Lawrence E, Cheetham $\mathrm{CH}$, Prentice AM, Hughes IA, McCamish MA \& O'Rahilly S (1999) Effects of recombinant leptin therapy in a child with congenital leptin deficiency. New England Journal of Medicine 341, 879-884.

Farooqi IS \& O'Rahilly S (2005) Monogenic obesity in humans. Annual Review of Medicine 56, 443-458.

Farooqi IS, Yeo GS, Keogh JM, Aminian S, Jebb SA, Butler G, Cheetham T \& O'Rahilly S (2000) Dominant and recessive inheritance of morbid obesity associated with melanocortin 4 receptor deficiency. Journal of Clinical Investigation 106, 271-279.

Farooqi IS, Yeo GS \& O'Rahilly S (2003) Binge eating as a phenotype of melanocortin 4 receptor gene mutations. New England Journal of Medicine 349, 606-609.

Fei H, Okano HJ, Li C, Lee GH, Zhao C, Darnell R \& Friedman JM (1997) Anatomic localization of alternatively 
spliced leptin receptors (Ob-R) in mouse brain and other tissues. Proceedings of the National Academy of Sciences USA 94, 7001-7005.

Feifel D \& Vaccarino FJ (1989) Feeding effects of growth hormone-releasing factor in rats are photoperiod sensitive. Behavioral Neuroscience 103, 824-830.

Feifel D \& Vaccarino FJ (1990) Central somatostatin: a reexamination of its effects on feeding. Brain Research 535, 189-194.

Feifel D \& Vaccarino FJ (1994) Growth hormone-regulatory peptides (GHRH and somatostatin) and feeding: a model for the integration of central and peripheral function. Neuroscience and Biobehavioral Reviews 18, 421-433.

Fekete C, Legradi G, Mihaly E, Huang QH, Tatro JB, Rand WM, Emerson CH \& Lechan RM (2000) $\alpha$-Melanocyte-stimulating hormone is contained in nerve terminals innervating thyrotropin-releasing hormone-synthesizing neurons in the hypothalamic paraventricular nucleus and prevents fasting-induced suppression of prothyrotropin-releasing hormone gene expression. Journal of Neuroscience 20, 1550-1558.

Fekete C, Sarkar S, Rand WM, Harney JW, Emerson CH, Bianco AC \& Lechan RM (2002) Agouti-related protein (AGRP) has a central inhibitory action on the hypothalamicpituitary-thyroid (HPT) axis; comparisons between the effect of AGRP and neuropeptide $\mathrm{Y}$ on energy homeostasis and the HPT axis. Endocrinology 143, 3846-3853.

Flier JS (2004) Obesity wars: molecular progress confronts an expanding epidemic. Cell 116, 337-350.

Flint A, Raben A, Astrup A \& Holst JJ (1998) Glucagon-like peptide 1 promotes satiety and suppresses energy intake in humans. Journal of Clinical Investigation 101, 515-520.

Flint A, Raben A, Ersboll AK, Holst JJ \& Astrup A (2001) The effect of physiological levels of glucagon-like peptide-1 on appetite, gastric emptying, energy and substrate metabolism in obesity. International Journal of Obesity and Related Metabolic Disorders 25, 781-792.

Flint A, Raben A, Rehfeld JF, Holst JJ \& Astrup A (2000) The effect of glucagon-like peptide-1 on energy expenditure and substrate metabolism in humans. International Journal of Obesity and Related Metabolic Disorders 24, 288-298.

Fodor M \& Delemarre-van de Waal HA (2001) Are POMC neurons targets for sex steroids in the arcuate nucleus of the rat? Neuroreport 12, 3989-3991.

Fodor M, Sluiter A, Frankhuijzen-Sierevogel A, Wiegant VM, Hoogerhout P, De Wildt DJ \& Versteeg DH (1996) Distribution of Lys-gamma 2-melanocyte-stimulating hormone-(Lysgamma 2-MSH)-like immunoreactivity in neuronal elements in the brain and peripheral tissues of the rat. Brain Research 731, 182-189.

Fogteloo AJ, Pijl H, Frolich M, McCamish M \& Meinders AE (2003) Effects of recombinant human leptin treatment as an adjunct of moderate energy restriction on body weight, resting energy expenditure and energy intake in obese humans. Diabetes Nutrition and Metabolism 16, 109-114.

Fraley GS, Dinh TT \& Ritter S (2002) Immunotoxic catecholamine lesions attenuate 2DG-induced increase of AGRP mRNA. Peptides 23, 1093-1099.

Frederich RC, Lollmann B, Hamann A, Napolitano-Rosen A, Kahn BB, Lowell BB \& Flier JS (1995) Expression of ob mRNA and its encoded protein in rodents. Impact of nutrition and obesity. Journal of Clinical Investigation 96, 1658-1663.

Friedman JM (2000) Obesity in the new millennium. Nature 404, 632-634.

Friedman JM (2003) A war on obesity, not the obese. Science 299, 856-858.

Friedman JM \& Halaas JL (1998) Leptin and the regulation of body weight in mammals. Nature 395, 763-770.
Fruebis J, Tsao TS, Javorschi S, Ebbets-Reed D, Erickson MR, Yen FT, Bihain BE \& Lodish HF (2001) Proteolytic cleavage product of $30-\mathrm{kDa}$ adipocyte complement-related protein increases fatty acid oxidation in muscle and causes weight loss in mice. Proceedings of the National Academy of Sciences USA 98, 2005-2010.

Fujimoto S, Inui A, Kiyota N, Seki W, Koide K, Takamiya S, Uemoto M, Nakajima Y, Baba S \& Kasuga M (1997) Increased cholecystokinin and pancreatic polypeptide responses to a fatrich meal in patients with restrictive but not bulimic anorexia nervosa. Biological Psychiatry 41, 1068-1070.

Fulton S, Pissios P, Manchon RP, Stiles L, Frank L, Pothos EN, Maratos-Flier E \& Flier JS (2006) Leptin regulation of the mesoaccumbens dopamine pathway. Neuron 51, 811-822.

Furuhata Y, Kagaya R, Hirabayashi K, Ikeda A, Chang KT, Nishihara M \& Takahashi M (2000) Development of obesity in transgenic rats with low circulating growth hormone levels: involvement of leptin resistance. European Journal of Endocrinology 143, 535-541.

García A, Alvarez CV, Smith RG \& Diéguez C (2001) Regulation of pit-1 expression by ghrelin and ghrp-6 through the gh secretagogue receptor. Molecular Endocrinology 15, 14841495.

García MC, Casanueva FF, Diéguez C \& Señarís R (2000) Gestational profile of leptin messenger ribonucleic acid (mRNA) content in the placenta and adipose tissue in the rat, and regulation of the mRNA levels of the leptin receptor subtypes in the hypothalamus during pregnancy and lactation. Biology of Reproduction 62, 698-703.

García MC, López M, Gualillo O, Seoane L, Diéguez C \& Señarís R (2003) Hypothalamic levels of NPY, MCH, and prepro-orexin mRNA during pregnancy and lactation in the rat: role of prolactin. FASEB Journal 17, 1392-1400.

García MC, Wernstedt I, Berndtsson A, Enge M, Bell M, Hultgren $\mathrm{O}$ et al. (2006) Mature-onset obesity in interleukin-1 receptor I knockout mice. Diabetes 55, 1205-1213.

Gaytan F, Barreiro ML, Chopin LK, Herington AC, Morales C, Pinilla L, Casanueva FF, Aguilar E, Dieguez C \& TenaSempere M (2003) Immunolocalization of ghrelin and its functional receptor, the type 1a growth hormone secretagogue receptor, in the cyclic human ovary. Journal of Clinical Endocrinology and Metabolism 88, 879-887.

Ghatei MA, Uttenthal LO, Christofides ND, Bryant MG \& Bloom SR (1983) Molecular forms of human enteroglucagon in tissue and plasma: plasma responses to nutrient stimuli in health and in disorders of the upper gastrointestinal tract. Journal of Clinical Endocrinology and Metabolism 57, 488-495.

Gibbs J, Fauser DJ, Rowe EA, Rolls BJ, Rolls ET \& Maddison SP (1979) Bombesin suppresses feeding in rats. Nature 282 , 208-210.

Gibbs J, Young RC \& Smith GP (1973) Cholecystokinin decreases food intake in rats. Journal of Comparative Physiology and Psychology 84, 488-495.

Glass MJ, Chan J \& Pickel VM (2002) Ultrastructural localization of neuropeptide Y Y1 receptors in the rat medial nucleus tractus solitarius: relationships with neuropeptide $\mathrm{Y}$ or catecholamine neurons. Journal of Neuroscience Research 67, 753-765.

Gooley JJ, Schomer A \& Saper CB (2006) The dorsomedial hypothalamic nucleus is critical for the expression of foodentrainable circadian rhythms. Nature Neuroscience 9, 398-407.

Grandt D, Schimiczek M, Beglinger C, Layer P, Goebell H, Eysselein VE \& Reeve JR Jr (1994) Two molecular forms of peptide YY (PYY) are abundant in human blood: characterization of a radioimmunoassay recognizing PYY 1-36 and PYY 3-36. Regulatory Peptides 51, 151-159. 
Griffond B, Risold PY, Jacquemard C, Colard C \& Fellmann D (1999) Insulin-induced hypoglycemia increases preprohypocretin (orexin) mRNA in the rat lateral hypothalamic area. Neuroscience Letters 262, 77-80.

Gropp E, Shanabrough M, Borok E, Xu AW, Janoschek R, Buch $\mathrm{T}$ et al. (2005) Agouti-related peptide-expressing neurons are mandatory for feeding. Nature Neuroscience $\mathbf{8}$, 1289-1291.

Grove KL \& Cowley MA (2005) Is ghrelin a signal for the development of metabolic systems? Journal of Clinical Investigation 115, 3393-3397.

Gualillo O, Caminos J, Blanco M, García-Caballero T, Kojima M, Kangawa K, Diéguez C \& Casanueva F (2001) Ghrelin, a novel placental-derived hormone. Endocrinology 142, 788-794.

Guan XM, Yu H, Palyha OC, McKee KK, Feighner SD, Sirinathsinghji DJ, Smith RG, Van Der Ploeg LH \& Howard AD (1997) Distribution of mRNA encoding the growth hormone secretagogue receptor in brain and peripheral tissues. Brain Research Molecular Brain Research 48, 23-29.

Gutzwiller JP, Goke B, Drewe J, Hildebrand P, Ketterer S, Handschin D, Winterhalder R, Conen D \& Beglinger C (1999) Glucagon-like peptide-1: a potent regulator of food intake in humans. Gut 44, 81-86.

Hagan JJ, Leslie RA, Patel S, Evans ML, Wattam TA, Holmes S et al. (1999) Orexin A activates locus coeruleus cell firing and increases arousal in the rat. Proceedings of the National Academy of Sciences USA 96, 10911-10916.

Hagan MM, Castaneda E, Sumaya IC, Fleming SM, Galloway J \& Moss DE (1998) The effect of hypothalamic peptide YY on hippocampal acetylcholine release in vivo: implications for limbic function in binge-eating behavior. Brain Research $\mathbf{8 0 5}$, 20-28.

Hahn TM, Breininger JF, Baskin DG \& Schwartz MW (1998) Coexpression of Agrp and NPY in fasting-activated hypothalamic neurons. Nature Neuroscience 1, 271-272.

Hakansson M, de Lecea L, Sutcliffe JG, Yanagisawa M \& Meister B (1999) Leptin receptor- and STAT3-immunoreactivities in hypocretin/orexin neurones of the lateral hypothalamus. Journal of Neuroendocrinology 11, 653-663.

Hakansson ML, Brown H, Ghilardi N, Skoda RC \& Meister B (1998) Leptin receptor immunoreactivity in chemically defined target neurons of the hypothalamus. Journal of Neuroscience 18, 559-572.

Halaas JL, Gajiwala KS, Maffei M, Cohen SL, Chait BT, Rabinowitz D, Lallone RL, Burley SK \& Friedman JM (1995) Weight-reducing effects of the plasma protein encoded by the obese gene. Science 269, 543-546.

Halatchev IG \& Cone RD (2005) Peripheral administration of PYY3-36 produces conditioned taste aversion in mice. Cell Metabolism 1, 159-168.

Halford JC \& Blundell JE (2000a) Pharmacology of appetite suppression. Progress in Drug Research 54, 25-58.

Halford JC \& Blundell JE (2000b) Separate systems for serotonin and leptin in appetite control. Annals of Medicine 32, 222-232.

Hansen TK, Dall R, Hosoda H, Kojima M, Kangawa K, Christiansen JS \& Jorgensen JO (2002) Weight loss increases circulating levels of ghrelin in human obesity. Clinical Endocrinology 56, 203-206.

Hara J, Beuckmann CT, Nambu T, Willie JT, Chemelli RM, Sinton CM, Sugiyama F, Yagami K, Goto K, Yanagisawa M \& Sakurai T (2001) Genetic ablation of orexin neurons in mice results in narcolepsy, hypophagia, and obesity. Neuron $\mathbf{3 0}$, 345-354.

Harfstrand A, Fuxe K, Agnati LF, Benfenati F \& Goldstein M (1986) Receptor autoradiographical evidence for high densities of 125I-neuropeptide $\mathrm{Y}$ binding sites in the nucleus tractus solitarius of the normal male rat. Acta Physiologica Scandinavica 128, 195-200.

Hayward MD, Pintar JE \& Low MJ (2002) Selective reward deficit in mice lacking beta-endorphin and enkephalin. Journal of Neuroscience 22, 8251-8258.

He W, Lam TK, Obici S \& Rossetti L (2006) Molecular disruption of hypothalamic nutrient sensing induces obesity. Nature Neuroscience 9, 227-233.

Hecherington A \& Ranson S (1942) The spontaneous activity and food intake of rats with hypothalamic lesions. American Journal of Physiology 136, 609-617.

Heisler LK, Cowley MA, Kishi T, Tecott LH, Fan W, Low MJ et al. (2003) Central serotonin and melanocortin pathways regulating energy homeostasis. Annals of the New York Academy of Sciences 994, 169-174.

Heisler LK, Cowley MA, Tecott LH, Fan W, Low MJ, Smart JL et al. (2002) Activation of central melanocortin pathways by fenfluramine. Science 297, 609-611.

Henry BA, Rao A, Ikenasio BA, Mountjoy KG, Tilbrook AJ \& Clarke IJ (2001) Differential expression of cocaine- and amphetamine-regulated transcript and agouti related-protein in chronically food-restricted sheep. Brain Research 918, 40-50.

Herrmann C, Goke R, Richter G, Fehmann HC, Arnold R \& Goke B (1995) Glucagon-like peptide-1 and glucose-dependent insulin-releasing polypeptide plasma levels in response to nutrients. Digestion 56, 117-126.

Heymsfield SB, Greenberg AS, Fujioka K, Dixon RM, Kushner R, Hunt T, Lubina JA, Patane J, Self B, Hunt P \& McCamish M (1999) Recombinant leptin for weight loss in obese and lean adults: a randomized, controlled, doseescalation trial. Journal of the American Medical Association 282, 1568-1575.

Hirasawa A, Tsumaya K, Awaji T, Katsuma S, Adachi T, Yamada M, Sugimoto Y, Miyazaki S \& Tsujimoto G (2005) Free fatty acids regulate gut incretin glucagon-like peptide-1 secretion through GPR120. Nature Medicine 11, 90-94.

Holst B, Egerod KL, Schild E, Vickers SP, Cheetham S, Gerlach LO, Storjohann L, Stidsen CE, Jones R, BeckSickinger AG \& Schwartz TW (2006) GPR39 signaling is stimulated by zinc ions but not by obestatin. Endocrinology 148, 13-20.

Hommel JD, Trinko R, Sears RM, Georgescu D, Liu ZW, Gao XB, Thurmon JJ, Marinelli M \& DiLeone RJ (2006) Leptin receptor signaling in midbrain dopamine neurons regulates feeding. Neuron 51, 801-810.

Horvath TL \& Diano S (2004) Opinion: The floating blueprint of hypothalamic feeding circuits. Nature Reviews Neuroscience $\mathbf{5}$, 662-667.

Horvath TL, Diano S, Sotonyi P, Heiman M \& Tschop M (2001) Minireview: ghrelin and the regulation of energy balance - a hypothalamic perspective. Endocrinology 142, 4163-4169.

Horvath TL, Diano S \& Tschop M (2004) Brain circuits regulating energy homeostasis. Neuroscientist 10, 235-246.

Horvath TL, Diano S \& van den Pol AN (1999) Synaptic interaction between hypocretin (orexin) and neuropeptide Y cells in the rodent and primate hypothalamus: a novel circuit implicated in metabolic and endocrine regulations. Journal of Neuroscience 19, 1072-1087.

Hotta K, Funahashi T, Bodkin NL, Ortmeyer HK, Arita Y, Hansen BC \& Matsuzawa Y (2001) Circulating concentrations of the adipocyte protein adiponectin are decreased in parallel with reduced insulin sensitivity during the progression to type 2 diabetes in rhesus monkeys. Diabetes 50, 1126-1133.

Howard JK, Cave BJ, Oksanen LJ, Tzameli I, Bjorbaek C \& Flier JS (2004) Enhanced leptin sensitivity and attenuation of diet-induced obesity in mice with haploinsufficiency of Socs3. Nature Medicine 10, 734-738. 
Hu E, Liang P \& Spiegelman BM (1996) AdipoQ is a novel adipose-specific gene dysregulated in obesity. Journal of Biological Chemistry 271, 10697-10703.

Hu Z, Cha SH, Chohnan S \& Lane MD (2003) Hypothalamic malonyl-CoA as a mediator of feeding behavior. Proceedings of the National Academy of Sciences USA 100, 12624-12629.

Hunter RG, Philpot K, Vicentic A, Dominguez G, Hubert GW \& Kuhar MJ (2004) CART in feeding and obesity. Trends in Endocrinology and Metabolism 15, 454-459.

Huszar D, Lynch CA, Fairchild-Huntress V, Dunmore JH, Fang Q, Berkemeier LR et al. (1997) Targeted disruption of the melanocortin-4 receptor results in obesity in mice. Cell $\mathbf{8 8}$, 131-141.

Ibrahim N, Bosch MA, Smart JL, Qiu J, Rubinstein M, Ronnekleiv OK, Low MJ \& Kelly MJ (2003) Hypothalamic proopiomelanocortin neurons are glucose responsive and express K(ATP) channels. Endocrinology 144, 1331-1340.

Ida T, Nakahara K, Kuroiwa T, Fukui K, Nakazato M, Murakami T \& Murakami N (2000) Both corticotropin releasing factor and neuropeptide $\mathrm{Y}$ are involved in the effect of orexin (hypocretin) on the food intake in rats. Neuroscience Letters 293, 119-122.

Iglesias MJ, Pineiro R, Blanco M, Gallego R, Dieguez C, Gualillo O, Gonzalez-Juanatey JR \& Lago F (2004) Growth hormone releasing peptide (ghrelin) is synthesized and secreted by cardiomyocytes. Cardiovascular Research 62, 481-488.

Inui A (1999) Neuropeptide Y feeding receptors: are multiple subtypes involved? Trends in Pharmacological Sciences 20, 43-46.

Jain MR, Horvath TL, Kalra PS \& Kalra SP (2000) Evidence that NPY Y1 receptors are involved in stimulation of feeding by orexins (hypocretins) in sated rats. Regulatory Peptides $\mathbf{8 7}$, $19-24$.

Johren O, Neidert SJ, Kummer M, Dendorfer A \& Dominiak P (2001) Prepro-orexin and orexin receptor mRNAs are differentially expressed in peripheral tissues of male and female rats. Endocrinology 142, 3324-3331.

Kalia M \& Sullivan JM (1982) Brainstem projections of sensory and motor components of the vagus nerve in the rat. Journal of Comparative Neurology 211, 248-265.

Kalra SP, Dube MG, Pu S, Xu B, Horvath TL \& Kalra PS (1999) Interacting appetite-regulating pathways in the hypothalamic regulation of body weight. Endocrine Reviews 20, 68-100.

Kalra SP, Dube MG, Sahu A, Phelps CP \& Kalra PS (1991) Neuropeptide $\mathrm{Y}$ secretion increases in the paraventricular nucleus in association with increased appetite for food. Proceedings of the National Academy of Sciences USA 88, 10931-10935.

Kamegai J, Tamura H, Shimizu T, Ishii S, Sugihara H \& Wakabayashi I (2001) Chronic central infusion of ghrelin increases hypothalamic neuropeptide $\mathrm{Y}$ and Agouti-related protein mRNA levels and body weight in rats. Diabetes 50, 2438-2443.

Kastin AJ, Akerstrom V \& Pan W (2002) Interactions of glucagon-like peptide-1 (GLP-1) with the blood-brain barrier. Journal of Molecular Neuroscience 18, 7-14.

Kawai Y, Inagaki S, Shiosaka S, Shibasaki T, Ling N, Tohyama M \& Shiotani Y (1984) The distribution and projection of gamma-melanocyte stimulating hormone in the rat brain: an immunohistochemical analysis. Brain Research 297, 21-32.

Kim EK, Miller I, Landree LE, Borisy-Rudin FF, Brown P, Tihan T, Townsend CA, Witters LA, Moran TH, Kuhajda FP \& Ronnett GV (2002) Expression of FAS within hypothalamic neurons: a model for decreased food intake after C75 treatment. American Journal of Physiology 283, E867-E879.

Kim EM, Grace MK, Welch CC, Billington CJ \& Levine AS (1999) STZ-induced diabetes decreases and insulin normalizes
POMC mRNA in arcuate nucleus and pituitary in rats. American Journal of Physiology 276, R1320-R1326.

King BM (2006) The rise, fall, and resurrection of the ventromedial hypothalamus in the regulation of feeding behavior and body weight. Physiology and Behavior 87, 221-244.

Kirchgessner AL \& Liu M (1999) Orexin synthesis and response in the gut. Neuron 24, 941-951.

Kissileff HR, Pi-Sunyer FX, Thornton J \& Smith GP (1981) C-terminal octapeptide of cholecystokinin decreases food intake in man. American Journal of Clinical Nutrition 34, 154-160.

Koch JE (2001) Delta(9)-THC stimulates food intake in Lewis rats: effects on chow, high-fat and sweet high-fat diets. Pharmacology, Biochemistry, and Behavior 68, 539-543.

Kojima M, Hosoda H, Date Y, Nakazato M, Matsuo H \& Kangawa K (1999) Ghrelin is a growth-hormone-releasing acylated peptide from stomach. Nature 402, 656-660.

Kola B, Hubina E, Tucci SA, Kirkham TC, Garcia EA, Mitchell SE, Williams LM, Hawley SA, Hardie DG, Grossman AB \& Korbonits M (2005) Cannabinoids and ghrelin have both central and peripheral metabolic and cardiac effects via AMPactivated protein kinase. Journal of Biological Chemistry 280, 25196-25201.

Konturek SJ, Konturek JW, Pawlik T \& Brzozowski T (2004) Brain-gut axis and its role in the control of food intake. Journal of Physiology and Pharmacology 55, 137-154.

Kotz CM, Teske JA, Levine JA \& Wang C (2002) Feeding and activity induced by orexin $\mathrm{A}$ in the lateral hypothalamus in rats. Regulatory Peptides 104, 27-32.

Koylu EO, Couceyro PR, Lambert PD \& Kuhar MJ (1998) Cocaine- and amphetamine-regulated transcript peptide immunohistochemical localization in the rat brain. Journal of Comparative Neurology 391, 115-132.

Kristensen P, Judge ME, Thim L, Ribel U, Christjansen KN, Wulff BS et al. (1998) Hypothalamic CART is a new anorectic peptide regulated by leptin. Nature 393, 72-76.

Krude H, Biebermann H, Luck W, Horn R, Brabant G \& Gruters A (1998) Severe early-onset obesity, adrenal insufficiency and red hair pigmentation caused by POMC mutations in humans. Nature Genetics 19, 155-157.

Ladenheim EE, Moore KA, Salorio CF, Mantey SA, Taylor JE, Coy DH, Jensen RT \& Moran TH (1997) Characterization of bombesin binding sites in the rat stomach. European Journal of Pharmacology 319, 245-251.

Ladyman SR \& Grattan DR (2004) Region specific reduction in leptin-induced phosphorylation of STAT3 in the rat hypothalamus is associated with leptin resistance during pregnancy. Endocrinology 145, 3704-3711.

Lam TK, Pocai A, Gutierrez-Juarez R, Obici S, Bryan J, AguilarBryan L, Schwartz GJ \& Rossetti L (2005a) Hypothalamic sensing of circulating fatty acids is required for glucose homeostasis. Nature Medicine 11, 320-327.

Lam TK, Schwartz GJ \& Rossetti L (2005b) Hypothalamic sensing of fatty acids. Nature Neuroscience 8, 579-584.

Langley K (1994) The neuroendocrine concept today. Annals of the New York Academy of Sciences 733, 1-17.

Larhammar D (1996) Structural diversity of receptors for neuropeptide Y, peptide YY and pancreatic polypeptide. Regulatory Peptides 65, 165-174.

Larsson LI \& Rehfeld JF (1978) Distribution of gastrin and CCK cells in the rat gastrointestinal tract. Evidence for the occurrence of three distinct cell types storing $\mathrm{COOH}$-terminal gastrin immunoreactivity. Histochemistry 58, 23-31.

Lassmann V, Vague P, Vialettes B \& Simon MC (1980) Low plasma levels of pancreatic polypeptide in obesity. Diabetes 29, 428-430.

Lawrence CB, Liu YL, Stock MJ \& Luckman SM (2004) Anorectic actions of prolactin-releasing peptide are mediated 
by corticotropin-releasing hormone receptors. American Journal of Physiology 286, R101-R107.

Lawrence CB, Snape AC, Baudoin FM \& Luckman SM (2002) Acute central ghrelin and GH secretagogues induce feeding and activate brain appetite centers. Endocrinology 143, 155162.

Le Quellec A, Kervran A, Blache P, Ciurana AJ \& Bataille D (1992) Oxyntomodulin-like immunoreactivity: diurnal profile of a new potential enterogastrone. Journal of Clinical Investigation 74, 1405-1409.

Lee GH, Proenca R, Montez JM, Carroll KM, Darvishzadeh JG, Lee JI \& Friedman JM (1996) Abnormal splicing of the leptin receptor in diabetic mice. Nature 379, 632-635.

Lee Y, Yang SP, Soares MJ \& Voogt JL (2000) Distribution of prolactin-releasing peptide mRNA in the rat brain. Brain Research Bulletin 51, 171-176.

Legradi G \& Lechan RM (1999) Agouti-related protein containing nerve terminals innervate thyrotropin- releasing hormone neurons in the hypothalamic paraventricular nucleus. Endocrinology 140, 3643-3652.

Lelliott CJ, López M, Curtis RK, Parker N, Laudes M, Yeo G et al. (2005) Transcript and metabolite analysis of the effects of tamoxifen in rat liver reveals inhibition of fatty acid synthesis in the presence of hepatic steatosis. FASEB Journal 19, 1108-1119.

Levin BE \& Dunn-Meynell AA (2002) Reduced central leptin sensitivity in rats with diet-induced obesity. American Journal of Physiology 283, R941-R948.

Levin BE, Dunn-Meynell AA \& Banks WA (2004) Obesity-prone rats have normal blood-brain barrier transport but defective central leptin signaling before obesity onset. American Journal of Physiology 286, R143-R150.

Li C, Chen P \& Smith MS (1998) The acute suckling stimulus induces expression of neuropeptide Y (NPY) in cells in the dorsomedial hypothalamus and increases NPY expression in the arcuate nucleus. Endocrinology 139, 16451652.

Lichtman AH \& Cravatt BF (2005) Food for thought: endocannabinoid modulation of lipogenesis. Journal of Clinical Investigation 115, 1130-1133.

Licinio J, Caglayan S, Ozata M, Yildiz BO, de Miranda PB, O'Kirwan F et al. (2004) Phenotypic effects of leptin replacement on morbid obesity, diabetes mellitus, hypogonadism, and behavior in leptin-deficient adults. Proceedings of the National Academy of Sciences USA 101, 4531-4536.

Loftus TM, Jaworsky DE, Frehywot GL, Townsend CA, Ronnett GV, Lane MD \& Kuhajda FP (2000) Reduced food intake and body weight in mice treated with fatty acid synthase inhibitors. Science 288, 2379-2381.

López M, Diéguez C \& Señarís R (2001a) The hypocretins/ orexins; a new bridge between sleep and feeding. In Recent Research in Endocrinology, pp. 87-98 [SG Pandalai, editor]. Kerala, India: Transworld Research Network.

López M, Lelliott CJ, Tovar S, Kimber W, Gallego R, Virtue S et al. (2006) Tamoxifen-induced anorexia is associated with fatty acid synthase inhibition in the ventromedial nucleus of the hypothalamus and accumulation of malonyl-CoA. Diabetes 55, 1327-1336.

López M, Senarís R, Gallego R, García-Caballero T, Lago F, Seoane L, Casanueva F \& Diéguez C (1999) Orexin receptors are expressed in the adrenal medulla of the rat. Endocrinology 140, 5991-5994.

López M, Seoane L, García MC, Lago F, Casanueva FF, Senarís R \& Diéguez C (2000) Leptin regulation of preproorexin and orexin receptor mRNA levels in the hypothalamus. Biochemical and Biophysical Research Communications 269, 41-45.
López M, Seoane LM, García MC, Diéguez C \& Señarís R (2002) Neuropeptide Y, but not agouti-related peptide or melanin-concentrating hormone, is a target peptide for orexin-a feeding actions in the rat hypothalamus. Neuroendocrinology 75, 34-44.

López M, Seoane L, Señarís R \& Diéguez C (2001b) Preproorexin mRNA levels in the rat hypothalamus, and orexin receptors mRNA levels in the rat hypothalamus and adrenal gland are not influenced by the thyroid status. Neuroscience Letters 300, 171-175.

López M, Seoane LM, Tovar S, García MC, Nogueiras R, Diéguez C \& Señarís RM (2005a) A possible role of neuropeptide $\mathrm{Y}$, agouti-related protein and leptin receptor isoforms in hypothalamic programming by perinatal feeding in the rat. Diabetologia 48, 140-148.

López M, Seoane LM, Tovar S, Nogueiras R, Diéguez C \& Señarís R (2004) Orexin-A regulates growth hormone releasing hormone mRNA content in a nucleus specific manner and somatostatin mRNA content in a growth hormone-dependent fashion in the rat hypothalamus. European Journal of Neuroscience 19, 2080-2088.

López M, Tena-Sempere M, García-Caballero T, Señarís R \& Diéguez C (2005b) Hypocretins in endocrine regulation. In Hypocretins. Integrators of Physiological Functions, pp. 393-421 [L de Lecea and JG Sutcliffe, editors]. New York: Springer Science.

Ludwig DS, Tritos NA, Mastaitis JW, Kulkarni R, Kokkotou E, Elmquist J, Lowell B, Flier JS \& Maratos-Flier E (2001) Melanin-concentrating hormone overexpression in transgenic mice leads to obesity and insulin resistance. Journal of Clinical Investigation 107, 379-386.

Luquet S, Perez FA, Hnasko TS \& Palmiter RD (2005) NPY/AgRP neurons are essential for feeding in adult mice but can be ablated in neonates. Science 310, 683-685.

Maeda N, Shimomura I, Kishida K, Nishizawa H, Matsuda M, Nagaretani $\mathrm{H}$ et al. (2002) Diet-induced insulin resistance in mice lacking adiponectin/ACRP30. Nature Medicine 8 , 731-737.

Maffei M, Halaas J, Ravussin E, Pratley RE, Lee GH, Zhang Y et al. (1995) Leptin levels in human and rodent: measurement of plasma leptin and ob RNA in obese and weight-reduced subjects. Nature Medicine 1, 1155-1161.

Maggi CA (1991) The pharmacology of the efferent function of sensory nerves. Journal of Autonomic Pharmacology 11, 173-208.

Majdic G, Young M, Gomez-Sanchez E, Anderson P, Szczepaniak LS, Dobbins RL, McGarry JD \& Parker KL (2002) Knockout mice lacking steroidogenic factor 1 are a novel genetic model of hypothalamic obesity. Endocrinology 143, 607-614.

Makimura H, Mizuno TM, Mastaitis JW, Agami R \& Mobbs CV (2002) Reducing hypothalamic AGRP by RNA interference increases metabolic rate and decreases body weight without influencing food intake. BMC Neuroscience 3, 18.

Malaisse-Lagae F, Carpentier JL, Patel YC, Malaisse WJ \& Orci L (1977) Pancreatic polypeptide: a possible role in the regulation of food intake in the mouse. Hypothesis. Experientia 33, 915-917.

Marcus JN, Aschkenasi CJ, Lee CE, Chemelli RM, Saper CB, Yanagisawa M \& Elmquist JK (2001) Differential expression of orexin receptors 1 and 2 in the rat brain. Journal of Comparative Neurology 435, 6-25.

Marks DL, Boucher N, Lanouette CM, Perusse L, Brookhart G, Comuzzie AG, Chagnon YC \& Cone RD (2004) Ala67Thr polymorphism in the Agouti-related peptide gene is associated with inherited leanness in humans. American Journal of Medical Genetics 126A, 267-271. 
Marks JL, Porte D Jr, Stahl WL \& Baskin DG (1990) Localization of insulin receptor mRNA in rat brain by in situ hybridization. Endocrinology 127, 3234-3236.

Marsh DJ, Weingarth DT, Novi DE, Chen HY, Trumbauer ME, Chen AS et al. (2002) Melanin-concentrating hormone 1 receptor-deficient mice are lean, hyperactive, and hyperphagic and have altered metabolism. Proceedings of the National Academy of Sciences USA 99, 3240-3245.

Masuzaki H, Ogawa Y, Sagawa N, Hosoda K, Matsumoto T, Mise H, Nishimura H, Yoshimasa Y, Tanaka I, Mori T \& Nakao K (1997) Nonadipose tissue production of leptin: leptin as a novel placenta-derived hormone in humans. Nature Medicine 3, 1029-1033.

Matsuda LA, Lolait SJ, Brownstein MJ, Young AC \& Bonner TI (1990) Structure of a cannabinoid receptor and functional expression of the cloned cDNA. Nature 346, 561-564.

Meeran K, O'Shea D, Edwards CM, Turton MD, Heath MM, Gunn I et al. (1999) Repeated intracerebroventricular administration of glucagon-like peptide-1-(7-36) amide or exendin(9-39) alters body weight in the rat. Endocrinology 140, 244-250.

Meier JJ, Gallwitz B, Schmidt WE \& Nauck MA (2002) Glucagon-like peptide 1 as a regulator of food intake and body weight: therapeutic perspectives. European Journal of Pharmacology 440, 269-279.

Mercer JG, Hoggard N, Williams LM, Lawrence CB, Hannah LT, Morgan PJ \& Trayhurn P (1996) Coexpression of leptin receptor and preproneuropeptide Y mRNA in arcuate nucleus of mouse hypothalamus. Journal of Neuroendocrinology $\mathbf{8}$, 733-735.

Mercer JG, Moar KM \& Hoggard N (1998) Localization of leptin receptor (Ob-R) messenger ribonucleic acid in the rodent hindbrain. Endocrinology 139, 29-34.

Minokoshi Y, Alquier T, Furukawa N, Kim YB, Lee A, Xue B et al. (2004) AMP-kinase regulates food intake by responding to hormonal and nutrient signals in the hypothalamus. Nature 428, 569-574.

Miyawaki K, Yamada Y, Ban N, Ihara Y, Tsukiyama K, Zhou $\mathrm{H}$ et al. (2002) Inhibition of gastric inhibitory polypeptide signaling prevents obesity. Nature Medicine 8, 738-742.

Moltz JH \& McDonald JK (1985) Neuropeptide Y: direct and indirect action on insulin secretion in the rat. Peptides 6, 11551159.

Montague CT, Farooqi IS, Whitehead JP, Soos MA, Rau H, Wareham NJ et al. (1997) Congenital leptin deficiency is associated with severe early-onset obesity in humans. Nature 387, 903-908.

Moran TH, Baldessarini AR, Salorio CF, Lowery T \& Schwartz GJ (1997) Vagal afferent and efferent contributions to the inhibition of food intake by cholecystokinin. American Journal of Physiology 272, R1245-R1251.

Moran TH, Norgren R, Crosby RJ \& McHugh PR (1990) Central and peripheral vagal transport of cholecystokinin binding sites occurs in afferent fibers. Brain Research 526, 95-102.

Moran TH, Robinson PH, Goldrich MS \& McHugh PR (1986) Two brain cholecystokinin receptors: implications for behavioral actions. Brain Research 362, 175-179.

Moran TH, Smedh U, Kinzig KP, Scott KA, Knipp S \& Ladenheim EE (2005) Peptide YY(3-36) inhibits gastric emptying and produces acute reductions in food intake in rhesus monkeys. American Journal of Physiology 288, R384-R388.

Morgan K, Obici S \& Rossetti L (2004) Hypothalamic responses to long-chain fatty acids are nutritionally regulated. Journal of Biological Chemistry 279, 31139-31148.

Moriguchi T, Sakurai T, Nambu T, Yanagisawa M \& Goto K (1999) Neurons containing orexin in the lateral hypothalamic area of the adult rat brain are activated by insulin-induced acute hypoglycemia. Neuroscience Letters 264, 101-104.

Morton GJ, Cummings DE, Baskin DG, Barsh GS \& Schwartz MW (2006) Central nervous system control of food intake and body weight. Nature 443, 289-295.

Mountjoy KG, Mortrud MT, Low MJ, Simerly RB \& Cone RD (1994) Localization of the melanocortin-4 receptor (MC4-R) in neuroendocrine and autonomic control circuits in the brain. Molecular Endocrinology 8, 1298-1308.

Munro S, Thomas KL \& Abu-Shaar M (1993) Molecular characterization of a peripheral receptor for cannabinoids. Nature 365, 61-65.

Munzberg H, Flier JS \& Bjorbaek C (2004) Region-specific leptin resistance within the hypothalamus of diet-induced-obese mice. Endocrinology 145, 4880-4889.

Munzberg H \& Myers MG (2005) Molecular and anatomical determinants of central leptin resistance. Nature Neuroscience 8, 566-570.

Muurahainen N, Kissileff HR, DeRogatis AJ \& Pi-Sunyer FX (1988) Effects of cholecystokinin-octapeptide (CCK-8) on food intake and gastric emptying in man. Physiology and Behavior 44, 645-649.

Nakazato M, Murakami N, Date Y, Kojima M, Matsuo H, Kangawa K \& Matsukura S (2001) A role for ghrelin in the central regulation of feeding. Nature 409, 194-198.

Naslund E, Barkeling B, King N, Gutniak M, Blundell JE, Holst JJ, Rossner S \& Hellstrom PM (1999) Energy intake and appetite are suppressed by glucagon-like peptide-1 (GLP-1) in obese men. International Journal of Obesity and Related Metabolic Disorders 23, 304-311.

Nogueiras R, Barreiro ML, Caminos JE, Gaytan F, Suominen JS, Navarro VM et al. (2004a) Novel expression of resistin in rat testis: functional role and regulation by nutritional status and hormonal factors. Journal of Cell Science 117, 3247-3257.

Nogueiras R, Gallego R, Gualillo O, Caminos JE, GarciaCaballero T, Casanueva FF \& Dieguez C (2003a) Resistin is expressed in different rat tissues and is regulated in a tissueand gender-specific manner. FEBS Letters 548, 21-27.

Nogueiras R, Gualillo O, Caminos JE, Casanueva FF \& Diéguez C (2003b) Regulation of resistin by gonadal, thyroid hormone, and nutritional status. Obesity Research 11, 408-414.

Nogueiras R, Pfluger P, Tovar S, Myrtha A, Mitchell S, Morris A et al. (2006) Effects of obestatin on energy balance and growth hormone secretion in rodents. Endocrinology 148, 21-26.

Nogueiras R, Tovar S, Mitchell SE, Rayner DV, Archer ZA, Diéguez C \& Williams LM (2004b) Regulation of growth hormone secretagogue receptor gene expression in the arcuate nuclei of the rat by leptin and ghrelin. Diabetes $\mathbf{5 3}$, 2552-2558.

Nogueiras R \& Tschop M (2005) Biomedicine. Separation of conjoined hormones yields appetite rivals. Science $\mathbf{3 1 0}$, 985-986.

Nonaka N, Shioda S, Niehoff ML \& Banks WA (2003) Characterization of blood-brain barrier permeability to PYY3-36 in the mouse. Journal of Pharmacology and Experimental Therapeutics 306, 948-953.

Obici S, Feng Z, Karkanias G, Baskin DG \& Rossetti L (2002a) Decreasing hypothalamic insulin receptors causes hyperphagia and insulin resistance in rats. Nature Neuroscience 5, 566-572.

Obici S, Feng Z, Morgan K, Stein D, Karkanias G \& Rossetti L (2002b) Central administration of oleic acid inhibits glucose production and food intake. Diabetes 51, 271-275.

Obici S, Feng Z, Tan J, Liu L, Karkanias G \& Rossetti L (2001) Central melanocortin receptors regulate insulin action. Journal of Clinical Investigation 108, 1079-1085.

Ohki-Hamazaki H, Watase K, Yamamoto K, Ogura H, Yamano M, Yamada K, Maeno H, Imaki J, Kikuyama S, Wada E \& 
Wada K (1997) Mice lacking bombesin receptor subtype-3 develop metabolic defects and obesity. Nature 390, 165-169.

Ollmann MM, Wilson BD, Yang YK, Kerns JA, Chen Y, Gantz I \& Barsh GS (1997) Antagonism of central melanocortin receptors in vitro and in vivo by agouti-related protein. Science 278, 135-138.

Pajvani UB, Du X, Combs TP, Berg AH, Rajala MW, Schulthess T, Engel J, Brownlee M \& Scherer PE (2003) Structurefunction studies of the adipocyte-secreted hormone Acrp30/ adiponectin. Implications for metabolic regulation and bioactivity. Journal of Biological Chemistry 278, 9073-9085.

Pelleymounter MA, Cullen MJ, Baker MB, Hecht R, Winters D, Boone T \& Collins F (1995) Effects of the obese gene product on body weight regulation in ob/ob mice. Science 269, 540 543.

Perez-Tilve D, Nogueiras R, Mallo F, Benoit SC \& Tschoep M (2006) Gut hormones ghrelin, PYY, and GLP-1 in the regulation of energy, balance, and metabolism. Endocrine 29, 61-72.

Pi-Sunyer X, Kissileff HR, Thornton J \& Smith GP (1982) C-terminal octapeptide of cholecystokinin decreases food intake in obese men. Physiology and Behavior 29, 627-630.

Pineiro R, Iglesias MJ, Gallego R, Raghay K, Eiras S, Rubio J, Dieguez C, Gualillo O, Gonzalez-Juanatey JR \& Lago F (2005) Adiponectin is synthesized and secreted by human and murine cardiomyocytes. FEBS Letters 579, 5163-5169.

Pinto S, Roseberry AG, Liu H, Diano S, Shanabrough M, Cai X, Friedman JM \& Horvath TL (2004) Rapid rewiring of arcuate nucleus feeding circuits by leptin. Science 304, 110-115.

Pocai A, Lam TK, Obici S, Gutierrez-Juarez R, Muse ED, Arduini A \& Rossetti L (2006) Restoration of hypothalamic lipid sensing normalizes energy and glucose homeostasis in overfed rats. Journal of Clinical Investigation 116, 1081-1091.

Qi Y, Takahashi N, Hileman SM, Patel HR, Berg AH, Pajvani UB, Scherer PE \& Ahima RS (2004) Adiponectin acts in the brain to decrease body weight. Nature Medicine 10, 524-529.

Qian S, Chen H, Weingarth D, Trumbauer ME, Novi DE, Guan X et al. (2002) Neither agouti-related protein nor neuropeptide $\mathrm{Y}$ is critically required for the regulation of energy homeostasis in mice. Molecular and Cellular Biology 22, 5027-5035.

Qu D, Ludwig DS, Gammeltoft S, Piper M, Pelleymounter MA, Cullen MJ, Mathes WF, Przypek R, Kanarek R \& MaratosFlier E (1996) A role for melanin-concentrating hormone in the central regulation of feeding behaviour. Nature 380, 243-247.

Reidelberger RD, Hernandez J, Fritzsch B \& Hulce M (2004) Abdominal vagal mediation of the satiety effects of CCK in rats. American Journal of Physiology 286, R1005-R1012.

Reidelberger RD \& Solomon TE (1986) Comparative effects of CCK-8 on feeding, sham feeding, and exocrine pancreatic secretion in rats. American Journal of Physiology 251, R97R105.

Roselli CE, Jorgensen EZ, Doyle MW \& Ronnekleiv OK (1997) Expression of the orphan receptor steroidogenic factor-1 mRNA in the rat medial basal hypothalamus. Brain Research Molecular Brain Research 44, 66-72.

Sakata I, Nakamura K, Yamazaki M, Matsubara M, Hayashi Y, Kangawa K \& Sakai T (2002) Ghrelin-producing cells exist as two types of cells, closed- and opened-type cells, in the rat gastrointestinal tract. Peptides 23, 531-536.

Sakurai T, Amemiya A, Ishii M, Matsuzaki I, Chemelli RM, Tanaka H et al. (1998) Orexins and orexin receptors: a family of hypothalamic neuropeptides and $\mathrm{G}$ protein-coupled receptors that regulate feeding behavior. Cell 92, 573-585.

Sanacora G, Kershaw M, Finkelstein JA \& White JD (1990) Increased hypothalamic content of preproneuropeptide $\mathrm{Y}$ messenger ribonucleic acid in genetically obese Zucker rats and its regulation by food deprivation. Endocrinology 127, 730-737.
Saper CB, Chou TC \& Elmquist JK (2002) The need to feed: homeostatic and hedonic control of eating. Neuron 36, 199-211.

Savage DB, Sewter CP, Klenk ES, Segal DG, Vidal-Puig A, Considine RV \& O'Rahilly S (2001) Resistin/Fizz3 expression in relation to obesity and peroxisome proliferator-activated receptor-gamma action in humans. Diabetes 50, 2199-2202.

Savontaus E, Conwell IM \& Wardlaw SL (2002) Effects of adrenalectomy on AGRP, POMC, NPY and CART gene expression in the basal hypothalamus of fed and fasted rats. Brain Research 958, 130-138.

Sawchenko PE (1983) Central connections of the sensory and motor nuclei of the vagus nerve. Journal of the Autonomic Nervous System 9, 13-26.

Sawchenko PE \& Swanson LW (1983) The organization and biochemical specificity of afferent projections to the paraventricular and supraoptic nuclei. Progress in Brain Research 60, 19-29.

Sawchenko PE, Swanson LW, Grzanna R, Howe PR, Bloom SR $\&$ Polak JM (1985) Colocalization of neuropeptide Y immunoreactivity in brainstem catecholaminergic neurons that project to the paraventricular nucleus of the hypothalamus. Journal of Comparative Neurology 241, 138-153.

Scherer PE, Williams S, Fogliano M, Baldini G \& Lodish HF (1995) A novel serum protein similar to C1q, produced exclusively in adipocytes. Journal of Biological Chemistry 270, 26746-26749.

Schmidt PT, Naslund E, Gryback P, Jacobsson H, Hartmann B, Holst JJ \& Hellstrom PM (2003) Peripheral administration of GLP-2 to humans has no effect on gastric emptying or satiety. Regulatory Peptides 116, 21-25.

Schobitz B, De Kloet ER, Sutanto W \& Holsboer F (1993) Cellular localization of interleukin 6 mRNA and interleukin 6 receptor mRNA in rat brain. European Journal of Neuroscience 5, 1426-1435.

Schwartz GJ \& Moran TH (1994) CCK elicits and modulates vagal afferent activity arising from gastric and duodenal sites. Annals of the New York Academy of Sciences 713, 121-128.

Schwartz MW, Figlewicz DP, Baskin DG, Woods SC \& Porte D $\mathrm{Jr}(1992 a)$ Insulin in the brain: a hormonal regulator of energy balance. Endocrine Reviews 13, 387-414.

Schwartz MW, Seeley RJ, Woods SC, Weigle DS, Campfield LA, Burn P \& Baskin DG (1997) Leptin increases hypothalamic pro-opiomelanocortin mRNA expression in the rostral arcuate nucleus. Diabetes 46, 2119-2123.

Schwartz MW, Sipols AJ, Marks JL, Sanacora G, White JD, Scheurink A et al. (1992b) Inhibition of hypothalamic neuropeptide Y gene expression by insulin. Endocrinology 130, 3608-3616.

Schwartz MW, Woods SC, Porte D Jr, Seeley RJ \& Baskin DG (2000) Central nervous system control of food intake. Nature 404, 661-671.

Scrocchi LA, Brown TJ \& Drucker DJ (1997) Leptin sensitivity in nonobese glucagon-like peptide I receptor -/- mice. Diabetes 46, 2029-2034.

Scrocchi LA, Brown TJ, Maclusky N, Brubaker PL, Auerbach AB, Joyner AL \& Drucker DJ (1996) Glucose intolerance but normal satiety in mice with a null mutation in the glucagonlike peptide 1 receptor gene. Nature Medicine 2, 1254-1258.

Scrocchi LA, Hill ME, Saleh J, Perkins B \& Drucker DJ (2000) Elimination of glucagon-like peptide 1R signaling does not modify weight gain and islet adaptation in mice with combined disruption of leptin and GLP-1 action. Diabetes 49, 15521560 .

Seal LJ, Small CJ, Dhillo WS, Stanley SA, Abbott CR, Ghatei MA \& Bloom SR (2001) PRL-releasing peptide inhibits food intake in male rats via the dorsomedial hypothalamic 
nucleus and not the paraventricular hypothalamic nucleus. Endocrinology 142, 4236-4243.

Seeber RM, Smith JT \& Waddell BJ (2002) Plasma leptinbinding activity and hypothalamic leptin receptor expression during pregnancy and lactation in the rat. Biology of Reproduction 66, 1762-1767.

Segal-Lieberman G, Bradley RL, Kokkotou E, Carlson M, Trombly DJ, Wang X, Bates S, Myers MG Jr, Flier JS \& Maratos-Flier E (2003) Melanin-concentrating hormone is a critical mediator of the leptin-deficient phenotype. Proceedings of the National Academy of Sciences USA 100, 10085-10090.

Señarís R, García-Caballero T, Casabiell X, Gallego R, Castro R, Considine RV, Diéguez C \& Casanueva FF (1997) Synthesis of leptin in human placenta. Endocrinology 138, 4501-4504.

Seoane LM, López M, Tovar S, Casanueva F, Señarís R \& Diéguez C (2003) Agouti-related peptide, neuropeptide Y, and somatostatin-producing neurons are targets for ghrelin actions in the rat hypothalamus. Endocrinology 144, 544-551.

Seoane LM, Tovar S, Baldelli R, Arvat E, Ghigo E, Casanueva FF \& Diéguez C (2000) Ghrelin elicits a marked stimulatory effect on GH secretion in freely-moving rats. European Journal of Endocrinology 143, R7-R9.

Seoane LM, Tovar S, Pérez D, Mallo F, López M, Señarís R, Casanueva FF \& Diéguez C (2004) Orexin A suppresses in vivo GH secretion. European Journal of Endocrinology 150, 731-736.

Sergeyev V, Broberger C, Gorbatyuk O \& Hokfelt T (2000) Effect of 2-mercaptoacetate and 2-deoxy-D-glucose administration on the expression of NPY, AGRP, POMC, MCH and hypocretin/orexin in the rat hypothalamus. Neuroreport 11, 117-121.

Shimada M, Tritos NA, Lowell BB, Flier JS \& Maratos-Flier E (1998) Mice lacking melanin-concentrating hormone are hypophagic and lean. Nature 396, 670-674.

Shimokawa T, Kumar MV \& Lane MD (2002) Effect of a fatty acid synthase inhibitor on food intake and expression of hypothalamic neuropeptides. Proceedings of the National Academy of Sciences USA 99, 66-71.

Shintani M, Ogawa Y, Ebihara K, Aizawa-Abe M, Miyanaga F, Takaya K et al. (2001) Ghrelin, an endogenous growth hormone secretagogue, is a novel orexigenic peptide that antagonizes leptin action through the activation of hypothalamic neuropeptide Y/Y1 receptor pathway. Diabetes 50, 227232.

Shughrue PJ, Lane MV \& Merchenthaler I (1996) Glucagon-like peptide-1 receptor (GLP1-R) mRNA in the rat hypothalamus. Endocrinology 137, 5159-5162.

Shughrue PJ, Lane MV \& Merchenthaler I (1997) Comparative distribution of estrogen receptor-alpha and -beta mRNA in the rat central nervous system. Journal of Comparative Neurology 388, 507-525.

Sipols AJ, Baskin DG \& Schwartz MW (1995) Effect of intracerebroventricular insulin infusion on diabetic hyperphagia and hypothalamic neuropeptide gene expression. Diabetes 44, 147-151.

Small CJ \& Bloom SR (2004) Gut hormones and the control of appetite. Trends in Endocrinology and Metabolism 15, 259-263.

Smith GP, Gibbs J, Jerome C, Pi-Sunyer FX, Kissileff HR \& Thornton J (1981a) The satiety effect of cholecystokinin: a progress report. Peptides 2, Suppl. 2, 57-59.

Smith GP, Jerome C \& Gibbs J (1981b) Abdominal vagotomy does not block the satiety effect of bombesin in the rat. Peptides 2, 409-411.

Spranger J, Verma S, Gohring I, Bobbert T, Seifert J, Sindler AL, Pfeiffer A, Hileman SM, Tschop M \& Banks WA (2006) Adiponectin does not cross the blood-brain barrier but modifies cytokine expression of brain endothelial cells. Diabetes 55, 141-147.

Stanley BG, Daniel DR, Chin AS \& Leibowitz SF (1985) Paraventricular nucleus injections of peptide YY and neuropeptide Y preferentially enhance carbohydrate ingestion. Peptides $\mathbf{6}$, 1205-1211.

Stanley BG, Kyrkouli SE, Lampert S \& Leibowitz SF (1986) Neuropeptide Y chronically injected into the hypothalamus: a powerful neurochemical inducer of hyperphagia and obesity. Peptides 7, 1189-1192.

Stanley S, Wynne K, McGowan B \& Bloom S (2005) Hormonal regulation of food intake. Physiological Reviews 85, 11311158.

Steininger TL, Kilduff TS, Behan M, Benca RM \& Landry CF (2004) Comparison of hypocretin/orexin and melaninconcentrating hormone neurons and axonal projections in the embryonic and postnatal rat brain. Journal of Chemical Neuroanatomy 27, 165-181.

Stephens TW, Basinski M, Bristow PK, Bue-Valleskey JM, Burgett SG, Craft L et al. (1995) The role of neuropeptide Y in the antiobesity action of the obese gene product. Nature 377, 530-532.

Steppan CM, Bailey ST, Bhat S, Brown EJ, Banerjee RR, Wright CM, Patel HR, Ahima RS \& Lazar MA (2001a) The hormone resistin links obesity to diabetes. Nature 409, 307-312.

Steppan CM, Brown EJ, Wright CM, Bhat S, Banerjee RR, Dai CY, Enders GH, Silberg DG, Wen X, Wu GD \& Lazar MA (2001b) A family of tissue-specific resistin-like molecules. Proceedings of the National Academy of Sciences USA 98, 502-506.

Steppan CM \& Lazar MA (2002) Resistin and obesity-associated insulin resistance. Trends in Endocrinology and Metabolism 13, 18-23.

Sternson SM, Shepherd GM \& Friedman JM (2005) Topographic mapping of $\mathrm{VMH}-$ arcuate nucleus microcircuits and their reorganization by fasting. Nature Neuroscience $\mathbf{8}, 1356$ 1363.

Strobel A, Issad T, Camoin L, Ozata M \& Strosberg AD (1998) A leptin missense mutation associated with hypogonadism and morbid obesity. Nature Genetics 18, 213-215.

Sul HS (2004) Resistin/ADSF/FIZZ3 in obesity and diabetes. Trends in Endocrinology and Metabolism 15, 247-249.

Sun Y, Ahmed S \& Smith RG (2003) Deletion of ghrelin impairs neither growth nor appetite. Molecular and Cellular Biology 23, 7973-7981.

Sun Y, Asnicar M, Saha PK, Chan L \& Smith RG (2006) Ablation of ghrelin improves the diabetic but not obese phenotype of ob/ob mice. Cell Metabolism 3, 379-386.

Sun Y, Wang P, Zheng H \& Smith RG (2004) Ghrelin stimulation of growth hormone release and appetite is mediated through the growth hormone secretagogue receptor. Proceedings of the National Academy of Sciences USA 101, 46794684.

Sutcliffe JG \& de Lecea L (2002) The hypocretins: setting the arousal threshold. Nature Reviews Neuroscience 3, 339-349.

Swart I, Jahng JW, Overton JM \& Houpt TA (2002) Hypothalamic NPY, AGRP, and POMC mRNA responses to leptin and refeeding in mice. American Journal of Physiology 283, R1020-R1026.

Szczypka MS, Kwok K, Brot MD, Marck BT, Matsumoto AM, Donahue BA \& Palmiter RD (2001) Dopamine production in the caudate putamen restores feeding in dopamine-deficient mice. Neuron 30, 819-828.

Taheri S, Zeitzer JM \& Mignot E (2002) The role of hypocretins (orexins) in sleep regulation and narcolepsy. Annual Review of Neuroscience 25, 283-313. 
Tamura H, Kamegai J, Shimizu T, Ishii S, Sugihara H \& Oikawa S (2002) Ghrelin stimulates GH but not food intake in arcuate nucleus ablated rats. Endocrinology 143, 3268-3275.

Tang-Christensen M, Vrang N \& Larsen PJ (2001) Glucagon-like peptide containing pathways in the regulation of feeding behaviour. International Journal of Obesity and Related Metabolic Disorders 25, Suppl. 5, S42-S47.

Tannenbaum GS, Lapointe M, Beaudet A \& Howard AD (1998) Expression of growth hormone secretagogue-receptors by growth hormone-releasing hormone neurons in the mediobasal hypothalamus. Endocrinology 139, 4420-4423.

Tartaglia LA (1997) The leptin receptor. Journal of Biological Chemistry 272, 6093-6096.

Tartaglia LA, Dembski M, Weng X, Deng N, Culpepper J, Devos R et al. (1995) Identification and expression cloning of a leptin receptor, OB-R. Cell 83, 1263-1271.

Tena-Sempere M, Barreiro ML, Gonzalez LC, Gaytan F, Zhang FP, Caminos JE, Pinilla L, Casanueva FF, Dieguez C \& Aguilar E (2002) Novel expression and functional role of ghrelin in rat testis. Endocrinology 143, 717-725.

Thiele TE, van Dijk G, Campfield LA, Smith FJ, Burn P, Woods SC, Bernstein IL \& Seeley RJ (1997) Central infusion of GLP1 , but not leptin, produces conditioned taste aversions in rats. American Journal of Physiology 272, R726-R730.

Toshinai K, Date Y, Murakami N, Shimada M, Mondal MS, Shimbara $\mathrm{T}$ et al. (2003) Ghrelin-induced food intake is mediated via the orexin pathway. Endocrinology 144, 15061512.

Tovar S, Nogueiras R, Tung LY, Castaneda TR, Vázquez MJ, Morris A, Williams LM, Dickson SL \& Diéguez C (2005) Central administration of resistin promotes short-term satiety in rats. European Journal of Endocrinology 153, R1-R5.

Tritos NA, Mastaitis JW, Kokkotou E \& Maratos-Flier E (2001) Characterization of melanin concentrating hormone and preproorexin expression in the murine hypothalamus. Brain Research 895, 160-166.

Tritos NA, Segal-Lieberman G, Vezeridis PS \& Maratos-Flier E (2004) Estradiol-induced anorexia is independent of leptin and melanin-concentrating hormone. Obesity Research 12, 716-724.

Tsao TS, Lodish HF \& Fruebis J (2002) ACRP30, a new hormone controlling fat and glucose metabolism. European Journal of Pharmacology 440, 213-221.

Tschop M, Castaneda TR, Joost HG, Thone-Reineke C, Ortmann S, Klaus S et al. (2004) Physiology: does gut hormone PYY3-36 decrease food intake in rodents? Nature 430, 1.

Tschop M, Smiley DL \& Heiman ML (2000) Ghrelin induces adiposity in rodents. Nature 407, 908-913.

Tschop M, Wawarta R, Riepl RL, Friedrich S, Bidlingmaier M, Landgraf R \& Folwaczny C (2001a) Post-prandial decrease of circulating human ghrelin levels. Journal of Endocrinological Investigation 24, RC19-RC21.

Tschop M, Weyer C, Tataranni PA, Devanarayan V, Ravussin E $\&$ Heiman ML (2001b) Circulating ghrelin levels are decreased in human obesity. Diabetes 50, 707-709.

Turton MD, O'Shea D, Gunn I, Beak SA, Edwards CM, Meeran $\mathrm{K}$ et al. (1996) A role for glucagon-like peptide- 1 in the central regulation of feeding. Nature 379, 69-72.

Uttenthal LO, Toledano A \& Blazquez E (1992) Autoradiographic localization of receptors for glucagon-like peptide-1 (7-36) amide in rat brain. Neuropeptides 21, 143-146.

Vaisse C, Halaas JL, Horvath CM, Darnell JE Jr, Stoffel M \& Friedman JM (1996) Leptin activation of Stat3 in the hypothalamus of wild-type and ob/ob mice but not $\mathrm{db} / \mathrm{db}$ mice. Nature Genetics 14, 95-97.

Valsamakis G, McTernan PG, Chetty R, Al Daghri N, Field A, Hanif W, Barnett AH \& Kumar S (2004) Modest weight loss and reduction in waist circumference after medical treatment are associated with favorable changes in serum adipocytokines. Metabolism 53, 430-434.

Van Heek M, Compton DS, France CF, Tedesco RP, Fawzi AB, Graziano MP, Sybertz EJ, Strader CD \& Davis HRJ (1997) Diet-induced obese mice develop peripheral, but not central, resistance to leptin. Journal of Clinical Investigation 99, 385390.

Verdich C, Flint A, Gutzwiller JP, Naslund E, Beglinger C, Hellstrom PM, Long SJ, Morgan LM, Holst JJ \& Astrup A (2001) A meta-analysis of the effect of glucagon-like peptide-1 (7-36) amide on ad libitum energy intake in humans. Journal of Clinical Endocrinology and Metabolism 86, 4382-4389.

Verty AN, McFarlane JR, McGregor IS \& Mallet PE (2004) Evidence for an interaction between $\mathrm{CB} 1$ cannabinoid and melanocortin MCR-4 receptors in regulating food intake. Endocrinology 145, 3224-3231.

Vidal-Puig A \& O'Rahilly S (2001) Resistin: a new link between obesity and insulin resistance? Clinical Endocrinology 55, 437-438.

Wallenius K, Wallenius V, Sunter D, Dickson SL \& Jansson JO (2002a) Intracerebroventricular interleukin-6 treatment decreases body fat in rats. Biochemical and Biophysical Research Communications 293, 560-565.

Wallenius V, Wallenius K, Ahren B, Rudling M, Carlsten H, Dickson SL, Ohlsson C \& Jansson JO (2002b) Interleukin-6deficient mice develop mature-onset obesity. Nature Medicine 8, 75-79.

Wang C \& Kotz CM (2002) Urocortin in the lateral septal area modulates feeding induced by orexin $\mathrm{A}$ in the lateral hypothalamus. American Journal of Physiology 283, R358-R367.

Wank SA, Harkins R, Jensen RT, Shapira H, de Weerth A \& Slattery T (1992a) Purification, molecular cloning, and functional expression of the cholecystokinin receptor from rat pancreas. Proceedings of the National Academy of Sciences USA 89, 3125-3129.

Wank SA, Pisegna JR \& de Weerth A (1992b) Brain and gastrointestinal cholecystokinin receptor family: structure and functional expression. Proceedings of the National Academy of Sciences USA 89, 8691-8695.

Wei Y \& Mojsov S (1995) Tissue-specific expression of the human receptor for glucagon-like peptide-I: brain, heart and pancreatic forms have the same deduced amino acid sequences. FEBS Letters 358, 219-224.

West DB, Fey D \& Woods SC (1984) Cholecystokinin persistently suppresses meal size but not food intake in free-feeding rats. American Journal of Physiology 246, R776-R787.

Wierup N, Richards WG, Bannon AW, Kuhar MJ, Ahren B \& Sundler F (2005) CART knock out mice have impaired insulin secretion and glucose intolerance, altered beta cell morphology and increased body weight. Regulatory Peptides 129, 203-211.

Willesen MG, Kristensen P \& Romer J (1999) Co-localization of growth hormone secretagogue receptor and NPY mRNA in the arcuate nucleus of the rat. Neuroendocrinology 70, 306-316.

Williams CM, Rogers PJ \& Kirkham TC (1998) Hyperphagia in pre-fed rats following oral delta9-THC. Physiology and Behavior 65, 343-346.

Williams DL, Kaplan JM \& Grill HJ (2000) The role of the dorsal vagal complex and the vagus nerve in feeding effects of melanocortin-3/4 receptor stimulation. Endocrinology 141, 1332-1337.

Williams G, Bing C, Cai XJ, Harrold JA, King PJ \& Liu XH (2001) The hypothalamus and the control of energy homeostasis: different circuits, different purposes. Physiology and Behavior 74, 683-701.

Williams G, Harrold JA \& Cutler DJ (2000) The hypothalamus and the regulation of energy homeostasis: lifting the lid 
on a black box. Proceedings of the Nutrition Society 59, 385396.

Willie JT, Chemelli RM, Sinton CM \& Yanagisawa M (2001) To eat or to sleep? Orexin in the regulation of feeding and wakefulness. Annual Review of Neuroscience 24, 429-458.

Winzell MS, Nogueiras R, Dieguez C \& Ahren B (2004) Dual action of adiponectin on insulin secretion in insulin-resistant mice. Biochemical and Biophysical Research Communications 321, 154-160.

Woods SC, Lotter EC, McKay LD \& Porte D Jr (1979) Chronic intracerebroventricular infusion of insulin reduces food intake and body weight of baboons. Nature 282, 503-505.

Woods SC, Seeley RJ, Baskin DG \& Schwartz MW (2003) Insulin and the blood-brain barrier. Current Pharmaceutical Design 9, 795-800.

Wortley KE, Del Rincon JP, Murray JD, García K, Iida K, Thorner MO \& Sleeman MW (2005) Absence of ghrelin protects against early-onset obesity. Journal of Clinical Investigation 115, 3573-3578.

Wren AM, Seal LJ, Cohen MA, Brynes AE, Frost GS, Murphy KG, Dhillo WS, Ghatei MA \& Bloom SR (2001a) Ghrelin enhances appetite and increases food intake in humans. Journal of Clinical Endocrinology and Metabolism 86, 5992.

Wren AM, Small CJ, Abbott CR, Dhillo WS, Seal L, Cohen MA, Batterham RL, Taheri S, Stanley SA, Ghatei MA \& Bloom SR (2001b) Ghrelin causes hyperphagia and obesity in rats. Diabetes 50, 2540-2547.

Wren AM, Small CJ, Ward HL, Murphy KG, Dakin CL, Taheri S, Kennedy AR, Roberts GH, Morgan DG, Ghatei MA \& Bloom SR (2000) The novel hypothalamic peptide ghrelin stimulates food intake and growth hormone secretion. Endocrinology 141, 4325-4328.

Wynne K, Stanley S \& Bloom S (2004) The gut and regulation of body weight. Journal of Clinical Endocrinology and Metabolism 89, 2576-2582.

Xu B, Goulding EH, Zang K, Cepoi D, Cone RD, Jones KR, Tecott LH \& Reichardt LF (2003) Brain-derived neurotrophic factor regulates energy balance downstream of melanocortin-4 receptor. Nature Neuroscience 6, 736-742.

Yamamoto H, Lee CE, Marcus JN, Williams TD, Overton JM, Lopez ME, Hollenberg AN, Baggio L, Saper CB, Drucker DJ \& Elmquist JK (2002) Glucagon-like peptide-1 receptor stimulation increases blood pressure and heart rate and activates autonomic regulatory neurons. Journal of Clinical Investigation 110, 43-52.

Yamanaka A, Beuckmann CT, Willie JT, Hara J, Tsujino N, Mieda M et al. (2003) Hypothalamic orexin neurons regulate arousal according to energy balance in mice. Neuron 38, 701713.

Yamanaka A, Kunii K, Nambu T, Tsujino N, Sakai A, Matsuzaki I, Miwa Y, Goto K \& Sakurai T (2000) Orexin-induced food intake involves neuropeptide Y pathway. Brain Research 859, 404-409.

Yamauchi T, Kamon J, Ito Y, Tsuchida A, Yokomizo T, Kita S et al. (2003) Cloning of adiponectin receptors that mediate antidiabetic metabolic effects. Nature 423, 762-769.
Yamauchi T, Kamon J, Minokoshi Y, Ito Y, Waki H, Uchida S et al. (2002) Adiponectin stimulates glucose utilization and fatty-acid oxidation by activating AMP-activated protein kinase. Nature Medicine 8, 1288-1295.

Yamauchi T, Kamon J, Waki H, Terauchi Y, Kubota N, Hara K et al. (2001) The fat-derived hormone adiponectin reverses insulin resistance associated with both lipoatrophy and obesity. Nature Medicine 7, 941-946.

Yaswen L, Diehl N, Brennan MB \& Hochgeschwender U (1999) Obesity in the mouse model of pro-opiomelanocortin deficiency responds to peripheral melanocortin. Nature Medicine 5, 1066-1070.

Yeo GS, Farooqi IS, Aminian S, Halsall DJ, Stanhope RG \& O'Rahilly S (1998) A frameshift mutation in MC4R associated with dominantly inherited human obesity. Nature Genetics $\mathbf{2 0}$, 111-112.

Yeomans MR, Wright P, Macleod HA \& Critchley JA (1990) Effects of nalmefene on feeding in humans. Dissociation of hunger and palatability. Psychopharmacology 100, 426432.

Yoshihara T, Honma S \& Honma K (1996) Effects of restricted daily feeding on neuropeptide $\mathrm{Y}$ release in the rat paraventricular nucleus. American Journal of Physiology 270, E589-E595.

Zarjevski N, Cusin I, Vettor R, Rohner-Jeanrenaud F \& Jeanrenaud B (1993) Chronic intracerebroventricular neuropeptide-Y administration to normal rats mimics hormonal and metabolic changes of obesity. Endocrinology 133, 17531758.

Zhang JV, Ren PG, Avsian-Kretchmer O, Luo CW, Rauch R, Klein C \& Hsueh AJ (2005) Obestatin, a peptide encoded by the ghrelin gene, opposes ghrelin's effects on food intake. Science 310, 996-999.

Zhang M, Balmadrid C \& Kelley AE (2003) Nucleus accumbens opioid, GABaergic, and dopaminergic modulation of palatable food motivation: contrasting effects revealed by a progressive ratio study in the rat. Behavioral Neuroscience 117, 202-211.

Zhang M \& Kelley AE (2000) Enhanced intake of high-fat food following striatal mu-opioid stimulation: microinjection mapping and fos expression. Neuroscience 99, 267-277.

Zhang Y, Proenca R, Maffei M, Barone M, Leopold L \& Friedman JM (1994) Positional cloning of the mouse obese gene and its human homologue. Nature 372, 425-432.

Zhu Y, Yamanaka A, Kunii K, Tsujino N, Goto K \& Sakurai T (2002) Orexin-mediated feeding behavior involves both leptinsensitive and -insensitive pathways. Physiology and Behavior 77, 251-257.

Zigman JM, Jones JE, Lee CE, Saper CB \& Elmquist JK (2006) Expression of ghrelin receptor mRNA in the rat and the mouse brain. Journal of Comparative Neurology 494, 528-548.

Zigman JM, Nakano Y, Coppari R, Balthasar N, Marcus JN, Lee CE et al. (2005) Mice lacking ghrelin receptors resist the development of diet-induced obesity. Journal of Clinical Investigation 115, 3564-3572. 